\title{
1 KDM6B interacts with TFDP1 to activate P53 signalling in regulating mouse
}

2 palatogenesis

3 5 6 7 9

Tingwei Guo, Xia Han, Jinzhi He, Jifan Feng, Junjun Jing, Eva Janečková, Jie Lei, Thach-Vu Ho, Jian $\mathrm{Xu}$ and Yang Chai*

Center for Craniofacial Molecular Biology, Herman Ostrow School of Dentistry, University of Southern California, Los Angeles, CA 90033, USA

Corresponding author:

Yang Chai

University Professor

George and MaryLou Boone Chair in Craniofacial Biology

Center for Craniofacial Molecular Biology

University of Southern California

2250 Alcazar Street - CSA 103

Los Angeles, CA 90033

Phone number: 323-442-3480

ychai@usc.edu

Key words: $K d m 6 b$, epigenetic regulation, $\operatorname{Trp} 53$, H3K27me3, $T f d p 1$, palatogenesis

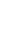
4 0 1 2 


\section{Abstract}

34 Epigenetic regulation plays extensive roles in diseases and development. Disruption of epigenetic regulation not only increases the risk of cancer, but can also cause various developmental defects. However, the question of how epigenetic changes lead to tissue-specific responses during neural crest

37 fate determination and differentiation remains understudied. Using palatogenesis as a model, we reveal the functional significance of $K d m 6 b$, a $\mathrm{H} 3 \mathrm{~K} 27 \mathrm{me} 3$ demethylase, in regulating mouse embryonic development. Our study shows that $K d m 6 b$ plays an essential role in cranial neural crest development, and loss of $K d m 6 b$ disturbs P53 pathway-mediated activity, leading to complete cleft palate along with

41 cell proliferation and differentiation defects in mice. Furthermore, activity of H3K27me 3 on the 42 promoter of $\operatorname{Trp} 53$ is antagonistically controlled by $K d m 6 b$, and $E z h 2$ in cranial neural crest cells. More

43 importantly, without $K d m 6 b$, the transcription factor TFDP1, which normally binds to the promoter of $44 \operatorname{Trp53}$, cannot activate Trp53 expression in palatal mesenchymal cells. Furthermore, the function of $45 K d m 6 b$ in activating Trp53 in these cells cannot be compensated for by the closely related histone 46 demethylase $K d m 6 a$. Collectively, our results highlight the important role of the epigenetic regulator 47 KDM6B and how it specifically interacts with TFDP1 to achieve its functional specificity in regulating $48 \quad \operatorname{Trp53}$ expression, and further provide mechanistic insights into the epigenetic regulatory network during 49 organogenesis. 


\section{Introduction}

53 Embryonic development is a highly complex self-assembly process during which precursor cells are

54 coordinated to generate appropriate cell types and assemble them into well-defined structures, tissues,

55 and organs (Shahbazi et al. 2016). During this process, precursor cells undergo extensive and rapid cell

56 proliferation until they reach the point of exit from the cell cycle to differentiate into various cell

57 lineages (Ruijtenberg and van den Heuvel 2016; Miermont et al. 2019). How these precursor cells

58 modulate expression of different genes and proceed through diverse proliferation and differentiation

59 processes is a very complex and interesting question. Growing evidence shows that epigenetic regulation,

60 which includes mechanisms such as DNA methylation, histone modifications, chromatin accessibility,

61 and higher-order organization of chromatin, provides the ability to modify gene expression and

62 associated protein production in a cell type-specific manner, thus playing an essential role in achieving

63 signaling specificity and in regulating cell fate during embryonic development (Hanna et al. 2018).

64 Among these various layers of epigenetic regulation, DNA methylation and histone methylation are the

65

66

67

68

69

70

71

72

73

74

best-characterized and known to be key regulators of diverse cellular events (Bannister and Kouzarides 2011; Smith and Meissner 2013; Molina-Serrano et al. 2019). For example, methylation of lysine 27 on histone $\mathrm{H} 3$ (H3K27me) by methyltransferases is a feature of heterochromatin that renders it inaccessible to transcription factors, thus maintaining transcriptional repression, across many species (Wiles and Selker 2017). On the other hand, methylation of H3K4me3 found near the promoter region can couple with the NURF complex to increase chromatin accessibility for gene activation (Wysocka et al. 2006; Soares et al. 2017). Demethylation, which results from removing a methyl group, also plays important roles during development. For instance, demethylation of $\mathrm{H} 3 \mathrm{~K} 4$ is required for maintaining pluripotency in embryonic stem cells, and demethylases KDM6A and KDM6B are required for proper gene expression in mature T cells (Lessard and Crabtree 2010; Jambhekar et al. 2019). These studies clearly 
show that failure to maintain epigenomic integrity can cause deleterious consequences for embryonic development and adult tissue homeostasis (Henckel et al. 2007; Kim et al. 2009; Kang et al. 2019).

Palatogenesis is a complex process known to be regulated by multiple genetic regulatory mechanisms, including several signaling pathways (BMP, SHH, WNT, FGF, and TGF $\beta$ ) and different transcription factors (such as Msx1, Sox9, Lhx6/8, Dlx5, Shox2 and more) (Satokata and Maas 1994; Yu et al. 2005; Chai and Maxson 2006; Levi et al. 2006; Cobourne et al. 2009; Lee and Saint-Jeannet 2011; Nakamura et al. 2011; Bush and Jiang 2012; He and Chen 2012; Parada and Chai 2012; Xu et al. 2016; Reynolds et al. 2019). However, environmental effects can also contribute to orofacial defects, which lends further support to the notion that genetic factors are not sufficient to fully explain the etiology of many birth defects (Dixon et al. 2011; Roessler et al. 2012; Seelan et al. 2012). Furthermore, case studies have revealed that heterozygous mutation of a chromatin-remodeling factor, $S A T B 2$, and variation in DNA methylation can cause cleft palate in patients (Leoyklang et al. 2007; Chandrasekharan and Ramanathan 2014; Young et al. 2021). These cases have drawn our attention to the function of epigenetic regulation in palatogenesis.

The contribution of cranial neural crest cells (CNCCs) is critical to palate mesenchyme formation. Recently, studies have begun to address the role of epigenetic regulation in neural crest cell fates determination during development. For instance, homozygous loss of Aridla, a subunit of SWI/SNF chromatin remodeling complex, in neural crest cells results in lethality in mice, associated with severe defects in the heart and craniofacial bones (Chandler and Magnuson 2016). In addition, both lysine methyltransferase $K m t 2 a$ and demethylase $K d m 6 a$ are essential for cardiac and neural crest development (Shpargel et al. 2017; Sen et al. 2020). However, how these epigenetic changes lead to tissue-specific response during neural crest fate determination remain to be elucidated. 
97 In this study, using palatogenesis as a model we investigated the functional significance of the 98 demethylase $K d m 6 b$ in regulating the fate of CNCCs during palatogenesis. We have discovered that loss 99 of $K d m 6 b$ in CNC-derived cells results in complete cleft palate along with soft palate muscle defects. 100 We also found cell proliferation and differentiation defects of CNC-derived cells in $K d m 6 b$ mutant mice. 101 More importantly, our study shows that the level of H3K27me3 on the promoter of Trp53 (also known 102 as P53 in human) is antagonistically controlled by $K d m 6 b$ and Ezh2. Furthermore, without $K d m 6 b$, the 103 transcription factor TFDP1, which binds to the promoter of $\operatorname{Trp53}$, cannot activate expression of $\operatorname{Trp53}$ 104 in palatal mesenchymal cells. More importantly, the function of $K d m 6 b$ in activating $\operatorname{Trp} 53$ in these cells 105 cannot be compensated for by the closely related histone demethylase Kdm6a. Our study highlights the 106 importance of epigenetic regulation on cell fate decision and its function in regulating activity of $\operatorname{Trp53}$ 107 in $\mathrm{CNC}$-derived cells during organogenesis. 


\section{Results}

\section{Loss of $K d m b b$ in $\mathrm{CNC}$-derived cells results in craniofacial malformations}

111 Previous research has shown that the X-chromosome-linked H3K27 demethylase KDM6A is 112 indispensable for neural crest cell differentiation and viability as it establishes appropriate chromatin 113 structure (Schwarz et al. 2014; Shpargel et al. 2017). However, we do not yet have a comprehensive 114 understanding of the roles of two other members of the KDM6 family, Kdm6b and Uty, in regulating 115 CNCCs during craniofacial development. More importantly, we have yet to understand how 116 demethylase achieves its functional specificity in regulating downstream target genes. In order to 117 elucidate the functions of $K d m 6 b$ and $U t y$, we first evaluated the expression patterns of KDM6 family 118 members in the palatal region (Figure 1-figure supplement $1 \mathrm{~A}-\mathrm{F}$ ). We found that, of these, $K d m 6 b$ is 119 more abundantly expressed than $K d m 6 a$ and Uty in both palate mesenchymal and epithelial cells, which 120 indicated it might play a critical role in regulating palatogenesis.

121 To investigate the tissue-specific function of $K d m 6 b$ during craniofacial development, we generated $122 W n t 1^{C r e} ; K d m 6 b^{f l f l}$ and $K r t 14^{C r e} ; K d m 6 b^{f l f l}$ mice to specifically target the deletion of $K d m 6 b$ in CNC123 derived and epithelial cells, respectively. Loss of $K d m 6 b$ in CNC-derived cells resulted in complete cleft 124 palate in $W n t 1^{C r e} ; K d m 6 b^{f l f l}$ mice $(90 \%$ phenotype penetrance, $\mathrm{N}=10)$ and postnatal lethality at newborn 125 stage $(100 \%$ phenotype penetrance, $\mathrm{N}=10)$ without interrupting expression of other KDM6 family 126 members (Figure 1-figure supplement $1 \mathrm{~A}-\mathrm{N}$ and Figure 1A-B). To evaluate when $K d m 6 b$ was 127 inactivated in the $\mathrm{CNC}$-derived cells, we also investigated the expression of $K d m 6 b$ at E9.5, well prior to 128 the formation of the palate primordium, and found that $K d m 6 b$ was efficiently inactivated in the $\mathrm{CNC}$ 129 derived cells at this stage (Figure 1-figure supplement 1O-P). Interestingly, loss of $K d m 6 b$ in epithelial 130 cells did not lead to obvious defects in the craniofacial region in $K r t 14^{C r e} ; K d m 6 b^{f l f l}$ mice ( Figure 1- 
131 figure supplement $2 \mathrm{~A}-\mathrm{H})$. These results emphasized that $K d m 6 b$ is specifically required in $\mathrm{CNC}$-derived 132 cells during palatogenesis. CT images also confirmed the complete cleft palate phenotype and revealed 133 that the most severe defects in the palatal region of $W n t 1^{C r e} ; K d m 6 b^{f l f l}$ mice were hypoplastic palatine 134 processes of the maxilla and palatine bones (Figure 1C-D). Except for a minor flattened skull, other 135 CNC-derived bones did not show significant differences between control and Wnt ${ }^{C r e} ; K d m 6 b^{f l f l}$ mice 136 (Figure 1-figure supplement 2I-N). To evaluate the phenotype in more detail, we performed histological 137 analysis and found that although the palatal shelves were able to elevate, the maxilla and palatine bones, 138 as well as the palate stromal mesenchyme and soft palate muscles, failed to grow towards the midline in $139 W n t 1^{C r e} ; K d m 6 b^{f l f l l}$ mice (Figure 1G-R and Figure 1-figure supplement 3A-P). Furthermore, in the 140 posterior soft palate region, $W n t 1^{C r e} ; K d m 6 b^{f l f l}$ mice also showed morphological defects related to the 141 orientation of muscle fibers and the pterygoid plate (Figure 1-figure supplement 3A-X). However, since 142 the soft palate forms subsequent to the hard palate, it is difficult to identify whether the soft palatal 143 muscle phenotype is a primary defect or a consequence resulting from an anterior cleft. Therefore, we 144 focused on the anterior hard palate for further investigation. Collectively, these data indicate that 145 mesenchymal $K d m 6 b$ is indispensable for craniofacial development and plays an essential role during 146 palatogenesis.

$K d m 6 b$ is critical for proliferation and differentiation of $\mathrm{CNC}$-derived palatal mesenchymal cells.

149 During craniofacial development, CNCCs migrate ventro-laterally and populate the branchial arches to 150 give rise to distinct mesenchymal structures in the head and neck, such as the palate. Failure of CNCCs 151 to populate pharyngeal arches causes craniofacial defects (Noden 1983; Noden 1991; Trainor and 152 Krumlauf 2000; Cordero et al. 2011). To determine whether Kdm6b mutant CNCCs successfully 153 populate the first pharyngeal arch, which gives rise to the palatal shelves, we generated tdTomato 
154 reporter mice and collected samples at E10.5. The results showed that CNCCs migration was not 155 adversely affected in $K d m 6 b$ mutant mice (Figure 2-figure supplement $1 \mathrm{~A}-\mathrm{B}$ ). Then we evaluated the 156 process of palatogenesis at different embryonic stages, and found that the cleft palate phenotype 157 emerged as early as E14.5 in $W n t 1^{C r e} ; K d m 6 b^{f l f l}$ mice (Figure 2-figure supplement 1C-D). These data 158 established that $K d m 6 b$ is not essential for CNCCs entering the pharyngeal arch but is specifically 159 required in regulating post-migratory CNC-derived cells during palatogenesis.

Because cell proliferation defects in CNC-derived cells frequently lead to craniofacial defects, we tested 161 whether loss of $K d m 6 b$ can affect cell proliferation using EdU labeling. After 2 hours of EdU labeling, we found that the number of cells positively stained with EdU were significantly increased in the CNCderived palatal mesenchyme in $W n t 1^{C r e} ; K d m 6 b^{f l f l}$ mice compared to controls (Figure 2A-C). In addition, 164 after 48 hours of EdU labeling, we found that the number of Ki67 and EdU double-positive cells was 165 significantly increased in $W n t 1^{C r e} ; K d m 6 b^{f l f l}$ mice (Figure 2D-H). These results indicated that loss of $166 K d m 6 b$ in CNC-derived cells resulted in more cells remaining in the cell cycle and actively proliferating, 167 which further led to hyperproliferation of mesenchymal cells in the palatal region of $W n t 1^{\text {Cre }} ; K d m 6 b^{f l f l}$ 168 mice. Meanwhile, palatal mesenchymal cells of $W n t 1^{C r e} ; K d m 6 b^{f l f l}$ mice showed more expression of $\beta$ 169 Galactosidase, which suggested increased cellular senescence in $W n t 1^{C r e} ; K d m 6 b^{f l f l}$ mice (Figure 2170 figure supplement $1 \mathrm{E}-\mathrm{G})$. To evaluate cellular senescence in vivo, we stained Lamin B1 in EdU-labeled 171 samples. After 48 hours of EdU labeling, we found there was less expression of Lamin B1 in the palatal 172 mesenchyme of $W n t 1^{C r e} ; K d m 6 b^{f l f l}$ mice. More importantly, fewer EdU+ cells express Lamin B1 were 173 observed in $W n t 1^{C r e} ; K d m 6 b^{f l f l}$ mice (Figure 2-figure supplement $1 \mathrm{H}-\mathrm{L}$ ). These data suggested that 174 hyperproliferation may cause increased cellular senescence in palatal mesenchymal cells of $175 \quad W n t 1^{C r e} ; K d m 6 b^{f l f l}$ mice. 
176 Typically, cell proliferation and differentiation are inversely correlated. Differentiation of precursor cells

177 is generally associated with arrested proliferation and permanently exiting the cell cycle (Ruijtenberg 178 and van den Heuvel 2016). To test whether cell differentiation was affected in the CNC-derived palatal 179 mesenchyme in $\mathrm{Wnt}^{\mathrm{Cre}} ; \mathrm{Kdm} 6 b^{\mathrm{fl} / f l}$ mice, we examined the distribution of the early osteogenesis marker RUNX2 and the later osteogenesis marker SP7 in the palatal region from E13.5 to E15.5 (Figure 2I-R). There was a decrease in the number of RUNX2+ cells in the palatal mesenchyme at both E13.5 and E14.5 in $W n t 1^{C r e} ; K d m 6 b^{f l f l}$ mice in comparison to the control (Figure 2I-L and Q). In addition, SP7+ cells were also decreased in $\mathrm{Wnt1}^{\mathrm{Cre}} ; \mathrm{Kdm} 6 b^{f l f l}$ mice at both E14.5 and E15.5 (Figure 2M-P and R).

Furthermore, when we induced osteogenic differentiation in palatal mesenchymal cells from E13.5 embryos for three weeks, we found that cells from $\mathrm{Wntl}^{\mathrm{Cre}} ; \mathrm{Kdm} 6 b^{f l f l}$ mice showed much less calcium deposition than cells from control mice, indicating a reduction in osteogenic potential in cells from $K d m 6 b$ mutant mice (Figure $2 \mathrm{~S}-\mathrm{W}$ ). These results indicated that $K d m 6 b$ was indispensable for maintaining normal proliferation and differentiation of CNC-derived cells.

\section{Loss of Kdm6b in CNC-derived cells disturbs P53 pathway-mediated activity}

In order to identify the downstream targets of $K d m 6 b$ in the palatal mesenchyme, we performed RNAseq analysis of palatal tissue at E12.5. The results showed that more genes were downregulated than upregulated in the palatal mesenchyme in $W n t 1^{C r e} ; K d m 6 b^{f l f l}$ mice (Figure 3A), which is consistent with the function of $K d m 6 b$ in removing the repressive mark H3K27me3. We further used Ingenuity Pathway Analysis (IPA) and Gene Ontology (GO) analysis to analyze the pathways that were most disturbed in the palatal mesenchyme in $K d m 6 b$ mutant mice. Surprisingly, both analyses indicated that pathways 
The tumor suppressor P53 plays prominent roles in regulating DNA damage response, including arresting cell growth for DNA repair, directing cellular senescence, and activating apoptosis (Mijit et al. 2020). Mutation of Trp53 is a major cause of cancer development (Williams and Schumacher 2016). Previous research has shown that some homozygous $\operatorname{Trp} 53$ mutant mice exhibit craniofacial defects including cleft palate, while inappropriate activation of Trp53 during embryogenesis also causes developmental defects including craniofacial abnormalities (Tateossian et al. 2015; Bowen et al. 2019). These results suggest that precise dosage of $\operatorname{Trp} 53$ is indispensable for craniofacial development. We analyzed expression of $\operatorname{Trp} 53$ in our samples and found that it significantly decreased in the palatal region of the $K d m 6 b$ mutant mice (Figure 3D-H). These results indicate that $K d m 6 b$ plays an important role in regulating the P53 pathway in the CNC-derived mesenchyme during palatogenesis. To further evaluate the consequence of downregulated $\operatorname{Trp} 53$ in $\mathrm{Wnt}^{\mathrm{Cre}} ; \mathrm{Kdm} 6 b^{f l f l}$ mice, we assessed DNA damage, which are tightly related to the function of $\operatorname{Trp} 53$, in our study. We found that DNA damage increased, as indicated by $\gamma \mathrm{H} 2 \mathrm{AX}$ expression, in the palatal mesenchyme in $\mathrm{Wntl}^{\mathrm{Cre}} ; \mathrm{Kdm} 6 b^{f l f l}$ mice (Figure 3I-M). More importantly, we observed significantly increased $\gamma \mathrm{H} 2 \mathrm{AX}$ foci in the EdU+ cells of $W n t 1^{C r e} ; K d m 6 b^{f l f l}$ palatal mesenchyme (Figure $3 \mathrm{~N}-\mathrm{R}$ ). These data indicated that actively proliferating cells in $\mathrm{Wntl}^{\mathrm{Cre}} ; \mathrm{Kdm} 6 b^{f l f f l}$ mice experienced more severe DNA damage compared to those in the control mice, which might be the result of replication stress caused by the hyperproliferation we observed in $W_{n t 1^{C r e}} ; K d m 6 b^{f l f l}$ mice.

\section{Altered $\operatorname{Trp} 53$ expression is responsible for the developmental defects in $\mathrm{Wnt1}^{\mathrm{Cre}} ; \mathrm{Kdm} \boldsymbol{\mathrm { C }} \mathrm{b}^{\mathrm{flfl} l}$ mice}

To further test whether downregulated expression of $\operatorname{Trp} 53$ is a key factor in the developmental defects we observed in $\mathrm{Wntl}^{\mathrm{Cr}} ; \mathrm{Kdm} 6 b^{f l f l}$ mice, we transfected palatal mesenchymal cells from control mice with siRNA to knock down $\operatorname{Trp} 53$. qPCR revealed that expression of $\operatorname{Trp} 53$ was significantly decreased 
221 in the cells treated with siRNA after three days (Figure 4-figure supplement 1A). At the same time, the 222 group transfected with siRNA for Trp53 showed a significant increase in EdU+ cells (Figure 4A-C). In 223 addition, significantly increased $\gamma \mathrm{H} 2 \mathrm{AX}+$ cells were also observed in the group transfected with siRNA 224 for $\operatorname{Trp53}$ (Figure 4D-F). These data suggested that downregulated expression of $\operatorname{Trp53}$ in the palatal 225 mesenchymal cells is a key factor that led to the hyperproliferation and increased DNA damage we 226 observed in $W n t 1^{C r e} ; K d m 6 b^{f l f l}$ mice. Furthermore, both expression of Runx2 and Sp7 were also 227 significantly reduced in the palatal mesenchymal cells transfected with siRNA for Trp53 (Figure 4228 figure supplement 1B-C), which indicated that downregulated expression of $\operatorname{Trp53}$ in the palatal 229 mesenchymal cells resulted in differentiation defects, which were also observed in $W n t 1^{C r e} ; K d m 6 b^{f l f l}$ 230 mice.

231 To further investigate the function of $\operatorname{Trp53}$ in $W n t 1^{C r e} ; K d m 6 b^{f l f l}$ mice, we tried to increase P53 in $232 K d m 6 b$ mutant mice using available small molecules. Previous research showed that MDM2, a ubiquitin 233 ligase, specifically targets P53 for degradation and there is increased P53 activity in Mdm2 mutant mice, 234 which exhibit a range of developmental defects (Arya et al. 2010; Bowen and Attardi 2019; Bowen et al. 235 2019). Nutlin-3, an MDM2 inhibitor that can specifically interrupt interaction between MDM2 and P53, 236 increases P53 in mouse primary neural stem progenitor cells and rescues neurogenic deficits in Fmrl 237 KO mice ( $\mathrm{Li}$ et al. 2016). We treated pregnant mice with Nutlin-3 at a dosage based on their body 238 weight at E10.5, E12.5 and E14.5 of pregnancy and then collected samples at E16.5 for analysis. To 239 assess the potential influence of the solvent used to dissolve Nutlin-3 (10\% DMSO in corn oil), we also 240 treated mice with $10 \%$ DMSO in corn oil at the same embryonic stages. None of the $K d m 6 b$ mutant 241 mice were rescued after this treatment $(\mathrm{N}=3)$ (Figure 4-figure supplement 1D-E). In contrast, Nutlin-3 242 treatment successfully rescued the cleft palate in three out of five $W n t 1^{C r e} ; K d m 6 b^{f l f l}$ mice (Figure 4G-R). 243 The remaining two showed a normal hard palate, but presented with posterior soft palate defects. 
244 Western blot analysis showed that the protein level of P53 was successfully restored in the Nutlin-3245 treated group (Figure 4-figure supplement 1F-G). This result further revealed that downregulation of $246 \operatorname{Trp53}$ in $W n t 1^{\mathrm{Cre}} ; K d m 6 b^{f l f l}$ mice plays an essential role in the palatal defects. The genetic interaction 247 between $K d m 6 b$ and Trp53 is important for the development of post-migratory CNCCs.

\section{Level of H3K27me3 is antagonistically regulated by $K d m 6 b$ and $E z h 2$ during palatogenesis}

The lysine-specific demethylase KDM6B is able to activate gene expression via removing the H3K27me3 repressive mark (Jiang et al. 2013). To investigate whether $K d m 6 b$ regulates the expression of Trp53 through modifying the level of $\mathrm{H} 3 \mathrm{~K} 27 \mathrm{me} 3$, we first examined the status of $\mathrm{H} 3 \mathrm{~K} 27 \mathrm{me} 3$ in our samples and found that loss of $K d m 6 b$ in CNC-derived cells resulted in accumulation of $\mathrm{H} 3 \mathrm{~K} 27 \mathrm{me} 3$ in the nucleus of CNC-derived palatal mesenchymal cells (Figure 5A-D). Furthermore, immunoblotting revealed that the level of $\mathrm{H} 3 \mathrm{~K} 27 \mathrm{me} 3$ was increased in the palatal region of $K d m 6 b$ mutant mice (Figure 5E). Since the level of H3K27me3 can also be modified by the methyltranferases EZH1 and EZH2, we further evaluated whether expression of EZH1 and EZH2 was affected in the palatal region. We found no obvious differences in either the distribution of Ezhl+ cells or the EZH1 protein level between control and $K d m 6 b$ mutant mice (Figure 5F-J). Similarly, no dramatic changes were observed in either the distribution of $\mathrm{EZH} 2+$ cells or its protein level between control and $K d m 6 b$ mutant mice (Figure 5KO). These results indicated that increased $\mathrm{H} 3 \mathrm{~K} 27 \mathrm{me} 3$ in $W n t 1^{C r e} ; K d m 6 b^{f l f l}$ mice was mainly caused by loss of $K d m 6 b$ in CNC-derived cells. However, we did notice a broader contribution and stronger signal of EZH2 than EZH1 in the CNC-derived palatal mesenchyme. To investigate whether an increase of 265 we generated $W n t 1^{C r e} ; K d m 6 b^{f l f l} ; E z h 2^{f l /+}$ mice and assessed the level of H3K27me3 in this model. In $W n t 1^{C r e} ; K d m 6 b^{f l f l} ; E z h 2^{f l /+}$ mice, we observed a rescue of the abnormal accumulation of H3K27me 3 
(Figure 5P-V). More importantly, haploinsufficiency of Ezh2 in this model successfully rescued the cleft palate phenotype observed in $W_{n t 1}^{C r e} ; K d m 6 b^{f l f l}$ mice (Figure 6A-O) with $70 \%$ efficiency $(\mathrm{N}=10)$. CT scanning showed that both the palatine processes of the maxilla and palatine bone were restored in the $W n t 1^{C r e} ; K d m 6 b^{f l f l} ; E z h 2^{f l /+}$ mice (Figure $\left.6 \mathrm{~A}-\mathrm{C}\right)$. Both bone and palatal mesenchymal tissue were rescued in $W n t 1^{C r e} ; K d m 6 b^{f l f f t} ; E z h 2^{f l /+}$ mice (Figure 6D-O). Furthermore, both EdU+ and RUNX2+ cells were restored to normal levels in $\mathrm{Wntl}^{\mathrm{Cre}} ; \mathrm{Kdm} 6 b^{f l f l} ; E z h 2^{f l /+}$ mice (Figure 7A-H). These results suggested that an antagonistic interaction between the histone demethylase KDM6B and methyltransferase EZH2 that modulates $\mathrm{H} 3 \mathrm{~K} 27 \mathrm{me} 3$ is essential for palatogenesis.

\section{$K d m 6 b$ activates expression of Trp53 through removing H3K27me3 at the promoter of Trp53 and} interacts with transcription factor TFDP1 in regulating P53 signaling pathway

Chromatin accessibility represents the degree to which chromatinized DNA is able to physically interact with nuclear macromolecules such as transcription factors for gene regulation (Klemm et al. 2019). The repressive mark $\mathrm{H} 3 \mathrm{~K} 27 \mathrm{me} 3$ is usually associated with facultative heterochromatin and results in transcriptional repression due to decreased chromatin accessibility (Wiles and Selker 2017; Moller et al. 2019; den Broeder et al. 2020). The methyltransferase EZH2 and demethylases KDM6A/KDM6B can regulate the methylation status of H3K27 to affect gene expression (Pediconi et al. 2019). To test whether $K d m 6 b$ and $E z h 2$ can regulate expression of $\operatorname{Trp} 53$ via H3K27me3, we first examined whether deposition of H3K27me3 changes at the promoter of Trp53 in our models using ChIP-qPCR. A primer set was designed at $1127 \mathrm{bp}$ upstream of $\operatorname{Trp} 53$ exon1 and the results showed that deposition of H3K27me3 significantly increased at the promoter of $\operatorname{Trp} 53$ in the palatal region of $K d m 6 b$ mutant mice, while this increase was dampened in the Ezh2 haploinsufficiency model (Figure 8A). Meanwhile, haplosufficiency of $E z h 2$ in $W n t 1^{C r e} ; K d m 6 b^{f l f l t} ; E z h 2^{f l /+}$ mice was able to restore the decreased expression 
of Trp53 observed in the CNC-derived palatal mesenchyme of $W n t 1^{C r e} ; K d m 6 b^{f l f l}$ mice (Figure $8 \mathrm{~B}-\mathrm{H}$ ).

291 These data suggested that $K d m 6 b$ and Ezh2 co-regulate expression of Trp53 through H3K27me3. To 292 further reveal whether KDM6B regulates the expression of Trp53 directly, we performed ChIP-qPCR 293 using KDM6B antibody and found that deposition of KDM6B significantly increased at the promoter of 294 Trp53 in the palatal region (Figure 8I). In addition, to test whether KDM6B has a unique role in 295 activating Trp53 during palatogenesis, we transfected palatal mesenchymal cells from $K d m 6 b$ mutant 296 mice with either a plasmid overexpressing $K d m 6 b$ or a plasmid overexpressing another histone 297 demethylase, $K d m 6 a$. Increased expression of Trp53 could be detected only in the group transfected 298 with $K d m 6 b$-overexpressing plasmid (Figure 8J-K and Figure 8-figure supplement 1A-B). These results 299 indicated that $K d m 6 b$ has an essential and unique role in activating $\operatorname{Trp} 53$ during palatogenesis.

300 As a H3K27me3 demethylase, KDM6B is important for the regulation of chromatin structure for gene 301 expression. To target a specific sequence in genome, a histone demethylase needs to interact with DNA 302 binding proteins such as transcription factors or IncRNAs (Dimitrova et al. 2015; Gurrion et al. 2017). 303 To identify a transcription factor that can interact with KDM6B, we performed ATAC-seq analysis of 304 palate tissue at E13.5. Through motif analysis we found that the promoter region of $\operatorname{Trp53}$ was 305 accessible to members of the E2F transcription factor family (E2F4 and E2F6) and transcription factor 306 TFDP1 (also known as Dp1), a binding partner of E2F family members (Figure 8L and Figure 8-figure 307 supplement 1C). We noticed that this open region was also located at the TSS of Wrap53, which was 308 previously reported to regulate endogenous Trp53 mRNA levels and P53 protein levels ((Mahmoudi et 309 al. 2009). To evaluate whether the decrease of Trp53 was caused by altered expression of Wrap53 in our 310 model, we examined expression of Wrap53 in the palatal region at E13.5. Almost no expression of 311 Wrap53 was detected in the palatal region (Figure 8-figure supplement 1D-E). Previous research 312 reported that inactivation of E2Fs resulted in milder phenotypes than those associated with loss of Tfdp1, 
313 which leads to early embryonic lethality (Kohn et al. 2003). This result suggested that TFDP1 may play

314 a more critical role than E2Fs during embryonic development. A motif of TFDP1 was detected 1011 bp 315 upstream of Trp53 exon 1, which is very close to the H3K27me3 deposition site, by ATAC-seq analysis. 316 ChIP-qPCR using palate tissue at E13.5 also revealed that binding of TFDP1 to the promoter region of 317 Trp53 decreased in the $K d m 6 b$ mutant mice (Figure 8M). Immunohistochemistry analysis showed that 318 TFDP1+ cells were distributed in the palatal region and co-expressed with $\operatorname{Trp53}$ and $K d m 6 b$ (Figure $3198 \mathrm{~N}-\mathrm{O}$ ). We also confirmed co-expression of $K d m 6 b$ and $T f d p l$ in the palatal region (especially enriched 320 in Pax9+, Aldhla2+ and Twist1+ cells) using our previously published scRNA-seq data (Figure 8-figure 321 supplement 1F) (Han et al. 2021). Meanwhile, the expression level and distribution of TFDP1 were not 322 affected in the palatal mesenchyme of $W n t 1^{C r e} ; K d m 6 b^{f l f l}$ mice (Figure 8P and Figure 8-figure 323 supplement $1 \mathrm{G}-\mathrm{H})$. These data indicated that $T f d p 1$ is not a downstream target of $K d m 6 b$. To further test 324 whether $T f d p 1$ regulated expression of Trp53 in the palatal mesenchymal cells, we transfected palatal 325 mesenchymal cells from control mice at E13.5 using siRNA to knock down Tfdp1. qPCR revealed that 326 the expression of Trp53 was decreased in cells treated with siRNA for Tfdpl (Figure 8-figure 327 supplement 1I and Figure 8Q). This data further indicated that Trp53 is a direct downstream target of $328 T f d p 1$.

329 To reveal the function of $K d m 6 b-T f d p l$ interaction in the regulation of Trp53 during palatogenesis, we 330 transfected palatal mesenchymal cells with $T f d p 1$-overexpressing plasmid and found that expression of 331 Trp53 increased in the cells from control mice but not in the cells from $W n t 1^{C r e} ; K d m 6 b^{f l f l}$ mice (Figure 332 8-figure supplement $1 \mathrm{~J}-\mathrm{K}$ and Figure $8 \mathrm{R}-\mathrm{S}$ ). This result suggested that $K d m 6 b$ is specifically required 333 and plays an essential role in activation of Trp53 through interaction with Tfdpl during palatogenesis. 334 We performed Co-IP experiments and found that KDM6B and TFDP1 were indeed involved in the same 335 complex (Figure 8T). Collectively, these data suggested that KDM6B and TFDP1 work together to 
336 activate Trp53 expression in the palatal mesenchyme and play an important role in regulating 337 palatogenesis (Figure 9).

\section{Discussion}

339 The development of an organism from a single cell to multiple different cell types requires tightly 340 regulated gene expression (Bruneau et al. 2019). Transcription factors, which are among the key 341 regulators of this process, are intimately involved in cell fate commitment (Nelms and Labosky 2010; 342 Soldatov et al. 2019). However, a transcription factor by itself cannot act on densely packed DNA in 343 chromatin form. Thus, transcription factors must work in coordination with epigenetic regulatory 344 mechanisms such as histone modifications, DNA methylation, chromatin remodeling and others to 345 dynamically regulate chromatin states for gene expression (Wilson and Filipp 2018; Gokbuget and 346 Blelloch 2019). Insults to the epigenetic landscape due to genetic, environmental or metabolic factors 347 can lead to diverse developmental defects and diseases (Hobbs et al. 2014; Zoghbi and Beaudet 2016; 348 Flavahan et al. 2017). Cleft palate comprises $30 \%$ of orofacial clefts, and can result from genetic 349 mutations, environmental effects, or a combination thereof (Seelan et al. 2012). Much progress has been 350 made in taking inventory of the gene mutations associated with craniofacial defects in recent years, and 351 growing evidence has shown that epigenetic regulation plays an important role during neural crest 352 development. For example, haploinsufficiency of KDM6A in humans causes severe psychomotor 353 developmental delay, global growth restriction, seizures and cleft palate (Lindgren et al. 2013). 354 Furthermore, studies have shown that Kdm6a and Aridla are both indispensable during neural crest 355 development (Chandler and Magnuson 2016; Shpargel et al. 2017). DNA methyltransferase3A 356 (DNMT3A) plays a critical role in mediating the transition from neural tube to neural crest fate (Hu et al. 357 2012). Meanwhile, loss of Ezh2, a component of PRC2, in CNC-derived cells completely prevents 358 craniofacial bone and cartilage formation (Schwarz et al. 2014). These studies have clearly shown that 
epigenetic regulation is crucial for neural crest development. In this study, we further demonstrate the important role of epigenetic regulation during the neural crest contribution to palate development using $W n t 1^{C r e} ; K d m 6 b^{f l f l}$ mice as a model. We show that the demethylase KDM6B is not only required for normal CNC-derived palatal mesenchymal cell proliferation, but also for maintaining cell differentiation.

Epigenetic regulators, transcription factors, and lineage-specific genes work together to achieve spatiotemporally restricted, tissue-specific gene regulation (Hu et al. 2014). In this study, we reveal that $K d m 6 b$ works with the transcription factor $T f d p 1$ to specifically regulate the expression of $\operatorname{Trp} 53$ during palatogenesis. The molecular mechanisms underlying the function of $\operatorname{Trp} 53$ in genomic stability and tumor suppression have been studied extensively. However, the role of $\operatorname{Trp} 53$ in regulating the development of CNC-derived cells still remains largely unclear, although several studies have been conducted recently on certain aspects of this topic. For instance, it has been shown that Trp53 is able to coordinate $\mathrm{CNC}$ cell growth and epithelial-mesenchymal transition/delamination processes by modulating cell cycle genes and proliferation (Rinon et al. 2011). It has also been established that both deletion and overexpression of Trp53 result in craniofacial defects (Tateossian et al. 2015; Bowen et al. 2019). Furthermore, nuclear stabilization of P53 protein in $T c f^{+/-}$mice induces neural crest cell progenitors to undergo cell-cycle arrest and caspase3-mediated apoptosis in the neuroepithelium. Inhibition of P53 function successfully rescues the neurocristopathy in an animal model of Treacher Collins syndrome, which results from mutation in Tcofl (Jones et al. 2008). These studies have clearly shown that appropriate function of $\operatorname{Trp} 53$ is indispensable in CNCCs. However, none of these studies have addressed upstream regulation of Trp53 in CNCCs.

Here, we show that proper function of Trp53 during the differentiation and proliferation of CNCCs is orchestrated by $K d m 6 b$ and $E z h 2$ through $\mathrm{H} 3 \mathrm{~K} 27 \mathrm{me} 3$. Altering the balance between $E z h 2$ and $K d m 6 b$ can cause abnormal $\mathrm{H} 3 \mathrm{~K} 27 \mathrm{me} 3$ function, which further affects the downstream transcription factor 
Trp53. In addition, we have detected spontaneous DNA damage in the developing palate and increased accumulation of DNA damage in the $W n t 1^{C r e} ; K d m 6 b^{f l f l}$ mice. These findings further demonstrate the critical function of Trp53 in protecting embryonic cells from DNA damage during development. Furthermore, the ability of cells to proliferate is limited by the length of the telomeres, which gradually shorten during each cell replication (Blagoev 2009). Once the telomeres are too short for DNA replication, the result is cellular senescence, which induces an irreversible inability to proliferate (Bernadotte et al. 2016). In this study we show that downregulated expression of Trp53 in $W n t 1^{C r e} ; K d m 6 b^{f l f l}$ mice results in hyperproliferation and increased DNA damage in the proliferative cells, which might further lead to increased cell senescence. Previous studies reported that few $\operatorname{Trp} 53^{-/}$ mice exhibit cleft palate or other craniofacial abnormalities, which suggests that loss of $\operatorname{Trp53}$ alone is not powerful enough to cause defects during craniofacial development (Rinon et al. 2011; Tateossian et al. 2015) and that there might be other factors which can compensate for loss of the function of Trp53. In our study, $W n t 1^{C r e} ; K d m 6 b^{f l f l}$ mice showed a cleft palate phenotype with high penetrance, and using MDM2 inhibitor Nutlin-3 we successfully rescued cleft palate in $K d m 6 b$ mutant mice. Our results suggested that in the $K d m 6 b$ mutant mice, the decrease of $\operatorname{Trp} 53$ cannot be compensated for by other factors, and disturbed P53 signaling is the key factor causing cleft palate in $K d m 6 b$ mutant mice.

Previous research has shown that KDM3A functions as a cofactor of STAT3 to activate the JAK2STAT3 signaling pathway (Kim et al. 2018) and that KDM2A coordinates with c-Fos in regulating COX-2 (Lu et al. 2015). Our study shows that KDM6B coordinates with the transcription factor TFDP1 to activate expression of Trp53 in CNCCs, and that Ezh2 and Kdm6b co-regulate $\mathrm{H} 3 \mathrm{~K} 27$ methylation status, which may affect the ability of TFDP1 to bind to the chromatin during palatogenesis. It has been reported that $T f d p 1$ is crucial for embryonic development and for regulating Wnt/ $\beta$-catenin signaling (Kohn et al. 2003; Kim et al. 2012). Interaction between KDM6B and TFDP1 discovered in this study 
405 further increases our knowledge of the coordination between epigenetic regulators and transcription 406 factors during organogenesis. As environmental insults can adversely affect the function of epigenetic 407 regulators, our findings provide a better understanding of the epigenetic regulation and transcription 408 factors involved in regulating the fate of $\mathrm{CNC}$ cells and craniofacial development, which can provide 409 important clues about human development, as well as potential therapeutic approaches for craniofacial 410 birth defects.

\section{$412 \quad$ Materials and Methods}

\section{$413 \quad$ Key resource table}

\begin{tabular}{|c|c|c|c|c|}
\hline $\begin{array}{l}\text { Reagent type } \\
\text { (species) or } \\
\text { resource }\end{array}$ & Designation & $\begin{array}{l}\text { Source or } \\
\text { reference }\end{array}$ & Identifiers & $\begin{array}{l}\text { Additional } \\
\text { information }\end{array}$ \\
\hline $\begin{array}{l}\text { Strain, strain } \\
\text { background (M. } \\
\text { musculus) }\end{array}$ & $K d m 6 b^{\text {flox/flox }}$ & $\begin{array}{l}\text { Manna et al. 2015, } \\
\text { Jackson Laboratory }\end{array}$ & $\begin{array}{l}\text { Stock No. } 029615 \\
\text { RRID:IMSR_JAX:029615 }\end{array}$ & \\
\hline $\begin{array}{l}\text { Strain, strain } \\
\text { background (M. } \\
\text { musculus) }\end{array}$ & Ezh $2^{\text {flox/flox }}$ & $\begin{array}{l}\text { Bildsoe et al., } \\
\text { 2009, Jackson } \\
\text { Laboratory }\end{array}$ & $\begin{array}{l}\text { Stock No. 022616; } \\
\text { RRID:IMSR_JAX:022616 }\end{array}$ & \\
\hline $\begin{array}{l}\text { Strain, strain } \\
\text { background (M. } \\
\text { musculus) }\end{array}$ & $\operatorname{Trp} 53^{\text {flox/flox }}$ & Jackson Laboratory & $\begin{array}{l}\text { Stock No. } 008462 \\
\text { RRID:IMSR_JAX:008462 }\end{array}$ & \\
\hline $\begin{array}{l}\text { Strain, strain } \\
\text { background (M. } \\
\text { musculus) }\end{array}$ & Wnt $1^{\text {Cre }}$ & Zhao et al. 2008 & & \\
\hline $\begin{array}{l}\text { Strain, strain } \\
\text { background (M. } \\
\text { musculus) }\end{array}$ & Krt1 $4^{\text {cre }}$ & Jackson Laboratory & $\begin{array}{l}\text { Stock No. 018964; } \\
\text { RRID:IMSR_JAX:018964 }\end{array}$ & \\
\hline
\end{tabular}




\begin{tabular}{|c|c|c|c|c|}
\hline $\begin{array}{l}\text { Reagent type } \\
\text { (species) or } \\
\text { resource }\end{array}$ & Designation & $\begin{array}{l}\text { Source or } \\
\text { reference }\end{array}$ & Identifiers & $\begin{array}{c}\text { Additional } \\
\text { information }\end{array}$ \\
\hline $\begin{array}{l}\text { Strain, strain } \\
\text { background (M. } \\
\text { musculus) }\end{array}$ & $\begin{array}{l}\text { ROSA26loxp-STOP- } \\
\text { loxp-tdTomato }\end{array}$ & Jackson Laboratory & $\begin{array}{l}\text { Stock No. 007905; } \\
\text { RRID:IMSR JAX:007905 }\end{array}$ & \\
\hline $\begin{array}{l}\text { Sequence-based } \\
\text { reagent }\end{array}$ & $\mathrm{Mm}-K d m 6 a$ probe & $\begin{array}{l}\text { Advanced Cell } \\
\text { Diagnostics }\end{array}$ & Cat\# 456961 & \\
\hline $\begin{array}{l}\text { Sequence-based } \\
\text { reagent }\end{array}$ & $\mathrm{Mm}-K d m 6 b$ probe & $\begin{array}{l}\text { Advanced Cell } \\
\text { Diagnostics }\end{array}$ & Cat\# 477971 & \\
\hline $\begin{array}{l}\text { Sequence-based } \\
\text { reagent }\end{array}$ & Mm-Kdm6b-01 probe & $\begin{array}{l}\text { Advanced Cell } \\
\text { Diagnostics }\end{array}$ & Cat\# 501231 & \\
\hline $\begin{array}{l}\text { Sequence-based } \\
\text { reagent }\end{array}$ & Mm-Uty probe & $\begin{array}{l}\text { Advanced Cell } \\
\text { Diagnostics }\end{array}$ & Cat\# 451741 & \\
\hline $\begin{array}{l}\text { Sequence-based } \\
\text { reagent }\end{array}$ & Mm-Trp53 probe & $\begin{array}{l}\text { Advanced Cell } \\
\text { Diagnostics }\end{array}$ & Cat\# 402331 & \\
\hline $\begin{array}{l}\text { Sequence-based } \\
\text { reagent }\end{array}$ & Mm-Trp53-C2 probe & $\begin{array}{l}\text { Advanced Cell } \\
\text { Diagnostics }\end{array}$ & Cat\# 402331-C2 & \\
\hline $\begin{array}{l}\text { Sequence-based } \\
\text { reagent }\end{array}$ & Mm-Ezhl probe & $\begin{array}{l}\text { Advanced Cell } \\
\text { Diagnostics }\end{array}$ & Cat\# 415501 & \\
\hline $\begin{array}{l}\text { Sequence-based } \\
\text { reagent }\end{array}$ & Mm-Wrap53 probe & $\begin{array}{l}\text { Advanced Cell } \\
\text { Diagnostics }\end{array}$ & Cat\# 1143201-C1 & \\
\hline Antibody & $\begin{array}{l}\text { Mouse monoclonal, } \\
\text { Myosin heavy chain } \\
\text { (MHC) }\end{array}$ & DSHB & Cat\# P13538 & $(1: 10)$ \\
\hline Antibody & $\begin{array}{l}\text { Rabbit monoclonal, } \\
\text { Histone H3 tri methyl } \\
\text { K27 }\end{array}$ & $\begin{array}{l}\text { Cell Signaling } \\
\text { Technology }\end{array}$ & Cat\# 9733s & $\begin{array}{l}(1: 200) \\
(1: 1000)\end{array}$ \\
\hline Antibody & $\begin{array}{l}\text { Rabbit monoclonal, } \\
\text { Phospho-Histone }\end{array}$ & $\begin{array}{l}\text { Cell Signaling } \\
\text { Technology }\end{array}$ & Cat\# 9718s & $(1: 200)$ \\
\hline
\end{tabular}




\begin{tabular}{|c|c|c|c|c|}
\hline $\begin{array}{l}\text { Reagent type } \\
\text { (species) or } \\
\text { resource }\end{array}$ & Designation & $\begin{array}{l}\text { Source or } \\
\text { reference }\end{array}$ & Identifiers & $\begin{array}{r}\text { Additional } \\
\text { information }\end{array}$ \\
\hline & H2A.X & & & \\
\hline Antibody & $\begin{array}{l}\text { Rabbit monoclonal, } \\
\text { DP1 }\end{array}$ & Abcam & Cat\# ab124678 & $\begin{array}{l}(1: 100) \\
(1: 1000)\end{array}$ \\
\hline Antibody & $\begin{array}{l}\text { Rabbit monoclonal, } \\
\text { EZH2 }\end{array}$ & $\begin{array}{l}\text { Cell Signaling } \\
\text { Technology }\end{array}$ & Cat\# 5246s & $\begin{array}{l}(1: 200) \\
(1: 2000)\end{array}$ \\
\hline Antibody & $\begin{array}{l}\text { Rabbit monoclonal, } \\
\text { RUNX2 }\end{array}$ & $\begin{array}{l}\text { Cell Signaling } \\
\text { Technology }\end{array}$ & Cat\# 12556s & $(1: 200)$ \\
\hline Antibody & $\begin{array}{l}\text { Rabbit polyclonal, } \\
\text { SP7 }\end{array}$ & Abcam & Cat\# ab22552 & $(1: 200)$ \\
\hline Antibody & $\begin{array}{l}\text { Rabbit monoclonal, } \\
\text { Lamin B1 }\end{array}$ & $\begin{array}{l}\text { Cell Signaling } \\
\text { Technology }\end{array}$ & Cat\# 17416s & $(1: 100)$ \\
\hline Antibody & \begin{tabular}{|l} 
Goat polyclonal anti- \\
Mouse Alexa Fluor 488
\end{tabular} & Life Technologies & Cat\# A11001 & $(1: 200)$ \\
\hline Antibody & $\begin{array}{l}\text { Goat polyclonal anti- } \\
\text { Mouse Alexa Fluor } 568\end{array}$ & Life Technologies & Cat\# A-11004 & $(1: 200)$ \\
\hline Antibody & $\begin{array}{l}\text { Goat polyclonal anti- } \\
\text { Rat Alexa Fluor } 488\end{array}$ & Life Technologies & Cat\# A-11006 & $(1: 200)$ \\
\hline Antibody & \begin{tabular}{|l} 
Goat polyclonal anti- \\
Rabbit Alexa Fluor 488
\end{tabular} & Life Technologies & Cat\# A-11008 & $(1: 200)$ \\
\hline Antibody & $\begin{array}{l}\text { Goat polyclonal anti- } \\
\text { Rabbit Alexa Fluor } 568\end{array}$ & Life Technologies & Cat\# A-11036 & $(1: 200)$ \\
\hline Antibody & $\begin{array}{l}\text { Rabbit polyclonal, } \\
\text { EZH1 }\end{array}$ & Abcam & Cat\# ab189833 & $(1: 1000)$ \\
\hline Antibody & $\begin{array}{l}\text { Rabbit polyclonal, } \\
\text { KDM6A }\end{array}$ & Abcam & Cat\# ab36938 & $(1: 1000)$ \\
\hline Antibody & $\begin{array}{l}\text { Rabbit polyclonal, } \\
\text { KDM6B (C-term) }\end{array}$ & AbCEPTA & Cat\# AP1022b & $(1: 1000)$ \\
\hline Antibody & Rabbit polyclonal, & AbCEPTA & Cat\# AP1022a & $(1: 1000)$ \\
\hline
\end{tabular}




\begin{tabular}{|c|c|c|c|c|}
\hline $\begin{array}{l}\text { Reagent type } \\
\text { (species) or } \\
\text { resource }\end{array}$ & Designation & $\begin{array}{l}\text { Source or } \\
\text { reference }\end{array}$ & Identifiers & $\begin{array}{c}\text { Additional } \\
\text { information }\end{array}$ \\
\hline & KDM6B (N-term) & & & \\
\hline Antibody & $\begin{array}{l}\text { Mouse monoclonal, } \\
\text { P53 }\end{array}$ & Santa Cruz & Cat\# sc-126 & $(1: 1000)$ \\
\hline Antibody & $\begin{array}{l}\text { Rabbit monoclonal, } \\
\text { Histone H3 }\end{array}$ & $\begin{array}{l}\text { Cell Signaling } \\
\text { Technology }\end{array}$ & Cat\# 4499s & $(1: 1000)$ \\
\hline Antibody & $\begin{array}{l}\text { Mouse monoclonal, } \\
\text { Beta Actin }\end{array}$ & Abcam & Cat\# Ab20272 & $(1: 2000)$ \\
\hline Antibody & $\begin{array}{l}\text { Goat polyclonal } \\
\text { Rabbit IgG HRP- } \\
\text { conjugated antibody }\end{array}$ & R\&D System & Cat\# HAF008 & $(1: 2000)$ \\
\hline Antibody & $\begin{array}{l}\text { Goat polyclonal } \\
\text { Mouse IgG HRP- } \\
\text { conjugated antibody }\end{array}$ & R\&D System & Cat\# HAF007 & $(1: 2000)$ \\
\hline Antibody & $\begin{array}{l}\text { Mouse monoclonal } \\
\text { HRP, Mouse Anti } \\
\text { Rabbit IgG LCS }\end{array}$ & IPKine & Cat\# A25022 & $(1: 2000)$ \\
\hline $\begin{array}{l}\text { Commercial } \\
\text { assay or kit }\end{array}$ & $\begin{array}{l}\text { Goat anti-mouse IgG } \\
\text { Alexa Fluor } 488 \\
\text { Tyramide SuperBoost } \\
\text { Kit }\end{array}$ & $\begin{array}{l}\text { ThermoFisher } \\
\text { Scientific }\end{array}$ & Cat\# B40912 & $(1: 200)$ \\
\hline $\begin{array}{l}\text { Commercial } \\
\text { assay or kit }\end{array}$ & $\begin{array}{l}\text { RNAscope Multiplex } \\
\text { Fluorescent Kit v2 }\end{array}$ & $\begin{array}{l}\text { Advanced Cell } \\
\text { Diagnostics }\end{array}$ & Cat\# 323110 & \\
\hline $\begin{array}{l}\text { Commercial } \\
\text { assay or kit }\end{array}$ & $\begin{array}{l}\text { RNAscope } 2.5 \mathrm{HD} \\
\text { Assay - RED }\end{array}$ & $\begin{array}{l}\text { Advanced Cell } \\
\text { Diagnostics }\end{array}$ & Cat\# 322350 & \\
\hline $\begin{array}{l}\text { Commercial } \\
\text { assay or kit }\end{array}$ & $\begin{array}{l}\text { TSA Plus Cyanine } 3 \\
\text { System }\end{array}$ & Perkin Elmer & Cat\# NEL744001KT & \\
\hline $\begin{array}{l}\text { Commercial } \\
\text { assay or kit }\end{array}$ & $\begin{array}{l}\text { TSA Plus Fluoresceine } \\
\text { System }\end{array}$ & Perkin Elmer & Cat\# NEL771B001KT & \\
\hline $\begin{array}{l}\text { Commercial } \\
\text { assay or kit }\end{array}$ & RNeasy Micro Kit & QIAGEN & Cat\# 74004 & \\
\hline Commercial & DAB Peroxidase (HRP) & Vector & RRID:AB_2336382 & \\
\hline
\end{tabular}




\begin{tabular}{|l|l|l|l|l|}
\hline $\begin{array}{c}\text { Reagent type } \\
\text { (species) or } \\
\text { resource }\end{array}$ & \multicolumn{1}{|c|}{ Designation } & \multicolumn{1}{c|}{$\begin{array}{c}\text { Source or } \\
\text { reference }\end{array}$} & $\begin{array}{c}\text { Additional } \\
\text { information }\end{array}$ \\
\hline $\begin{array}{l}\text { assay or kit } \\
\text { Nickel) }\end{array}$ & $\begin{array}{l}\text { Substrate Kit (With } \\
\text { algorithm }\end{array}$ & Laboratories & Cat\# SK4100 & RIH \\
\hline $\begin{array}{l}\text { Software, } \\
\text { algorithm }\end{array}$ & $\begin{array}{l}\text { Ingenuity Pathway } \\
\text { Analysis }\end{array}$ & Qiagen.Inc & RRID:SCR_008653 & \\
\hline $\begin{array}{l}\text { Software, } \\
\text { algorithm }\end{array}$ & GraphPad Prism & GraphPad Software & RRID:SCR_002798 & \\
\hline Software, & Seurat & Satija lab & RRID:SCR_016341 & \\
\hline algorithm & Cell ranger & $10 X$ Genomics.Inc & RRID:SCR_017344 & \\
\hline Software, \\
algorithm
\end{tabular}

\section{Animals}

417 To generate $W n t 1^{C r e} ; K d m 6 b^{f l f l}$ mice, we crossed $W n t 1^{C r e} ; K d m 6 b^{f l /+}$ mice with $K d m 6 b^{f l f l}$ mice (Zhao et 418 al. 2008; Manna et al. 2015). Reporter mice used in this study were tdTomato conditional reporter 419 (JAX\#007905) (Madisen et al. 2010). Ezh2 $2^{f l f l}$ and Trp53 $3^{f l f l}$ mice were purchased from Jackson 420 Laboratory (JAX\#022616, \#008462) (Marino et al. 2000; Shen et al. 2008). Genotyping was carried out 421 as previously described (Zhao et al. 2008). Briefly, tail samples were lysed by using DirectPCR tail 422 solution (Viagen $102 \mathrm{~T}$ ) with overnight incubation at $55^{\circ} \mathrm{C}$. After heat inactivation at $85^{\circ} \mathrm{C}$ for 1 hour, 423 PCR-based genotyping (GoTaq Green MasterMix, Promega, and C1000 Touch Cycler, Bio-rad) was 424 used to detect the genes. All mouse studies were conducted with protocols approved by the Department 425 of Animal Resources and the Institutional Animal Care and Use Committee (IACUC) of the University 426 of Southern California (Protocols 9320 and 20299). 
428 MicroCT was used to analyze the control, $K d m 6 b$, and other mutant samples. Mouse samples were 429 dissected and fixed in $4 \%$ paraformaldehyde overnight at $4{ }^{\circ} \mathrm{C}$ followed by CT scanning (Scanco 430 Medical $\mu$ CT50 scanner) at the University of Southern California Molecular Imaging Center as 431 previously described (Grosshans et al. 2006; Sugii et al. 2017). AVIZO 9.1.0 (Visualization Sciences 432 Group) was used for visualization and 3D microCT reconstruction.

433

434 435 436 437 438 439 440 441 442 443 444 445 446 447 448

\section{Alcian blue-Alizarin red staining}

Mouse heads were dissected and fixed in $95 \%$ EtOH overnight at room temperature. Staining was performed as previously described (Rigueur and Lyons 2014). Briefly, 95\% EtOH was replaced with $100 \%$ acetone for 2 days and then samples were incubated in Alcian blue solution (80\% EtOH, 20\% glacial acetic acid, and 0.03\% (w/v) Alcian blue 8GX (Sigma, A3157) for 1-3 days. Samples were then de-stained with $70 \% \mathrm{EtOH}$ and incubated in $95 \% \mathrm{EtOH}$ overnight. After incubation, samples were precleared with $1 \% \mathrm{KOH}$ and then incubated in Alizarin red solution $(0.005 \%$ (w/v) Alizarin red (Sigma, A5533) in $1 \%(\mathrm{w} / \mathrm{v}) \mathrm{KOH}$ ) for 2-5 days. After clearing samples with $1 \% \mathrm{KOH}$, they were stored in $100 \%$ glycerol until analysis.

\section{Sample preparation for sectioning}

Samples for paraffin sectioning were prepared using the standard protocol in our laboratory. Briefly, samples were fixed in 4\% PFA and decalcified with $10 \%$ EDTA as needed. Then, samples were dehydrated with serial ethanol solutions $(50 \%, 70 \%, 80 \%, 90 \%$ and $100 \%)$ at room temperature followed by xylene and then embedded in paraffin wax. Sections were cut to $6 \mu \mathrm{m}$ on a microtome (Leica) and mounted on SuperFrost Plus slides (Fisher, 48311-703). Cryosectioning samples were fixed and decalcified the same way as samples prepared for paraffin sectioning. Sucrose (15\% and $30 \%)$ was 
449 used to remove water from the samples before embedding them in OCT compound (Tissue-Tek, 4583).

450 Cryosections were cut to $8 \mu \mathrm{m}$ on a cryostat (Leica) and mounted on SuperFrost Plus slides (Fisher).

\section{$451 \quad$ Histological analysis}

452 Paraffin sections prepared as described above were used for histological analysis. Hematoxylin and 453 Eosin staining were performed using the standard protocol (Cardiff et al. 2014).

\section{Immunofluorescence assay}

455 Cryosections and paraffin sections prepared as described above were used for immunofluorescence 456 assays. Sections were dried for 2 hours at $55^{\circ} \mathrm{C}$. Paraffin sections were deparaffinized and rehydrated 457 before antigen retrieval. Heat mediated antigen retrieval was used to process sections (Vector, H-3300) 458 and then samples were blocked for 1 hour in blocking buffer at room temperature (PerkinElmer, 459 FP1020). Primary antibodies diluted in blocking buffer were incubated with samples overnight at $4^{\circ} \mathrm{C}$. 460 After washing with PBST (0.1\% Tween20 in 1xPBS), samples were then incubated with secondary 461 antibodies at room temperature for 2 hours. DAPI (Sigma, D9542) was used for nuclear staining. All 462 images were acquired using Leica DMI 3000B and Keyence BZ-X710/810 microscopes. Detailed 463 information about primary and secondary antibodies is listed in Supplementary File 1.

\section{EdU labeling}

465 EdU solution was prepared at $10 \mathrm{mg} / \mathrm{mL}$ in PBS, and then pregnant mice at the desired stage were given 466 an intra-peritoneal injection (IP) based on their weight ( $0.1 \mathrm{mg}$ of EdU/1 $\mathrm{g}$ of mouse). Embryos were 467 collected after 2 hours or 48 hours and then prepared for sectioning as above. EdU signal was detected 468 using Click-It EdU cell proliferation kit (Invitrogen, C10337) and images were acquired using Leica 469 DMI 3000B and Keyence BZ-X710/810 microscopes. 


\section{RNAscope in situ hybridization}

471 RNAscope in situ hybridization in this study was performed on cryosections using RNAscope 2.5HD

472 Reagent Kit-RED assay (Advanced Cell Diagnostics, 322350) and RNAscope multiplex fluorescent v2 473 assay (Advanced Cell Diagnostics, 323100) according to the manufacturer's protocol. RNAscope probes 474 used in this study included $K d m 6 a, K d m 6 b$, Uty, and Trp53. Detailed information about probes is listed 475 in Supplementary File 2.

$476 \quad$ RNA-sequencing and analysis

477 Palate samples from control and $W n t 1^{C r e} ; K d m 6 b^{f l f l}$ mice were collected at E12.5 for RNA isolation with 478 RNeasy Micro Kit (Qiagen) according to the manufacturer's protocol. The quality of RNA samples was 479 determined using an Agilent 2100 Bioanalyzer and all samples for sequencing had RNA integrity (RIN) 480 numbers $>$ 9. cDNA library preparation and sequencing were performed at the USC Molecular 481 Genomics Core. Single-end reads with 75 cycles were performed on Illumina Hiseq 4000 equipment and 482 raw reads were trimmed and aligned using TopHat (Version 2.0.8) with the mm10 genome. CPM was 483 used to normalize the data and differential expression was calculated by selecting transcripts that 484 changed with $\mathrm{p}<0.05$.

485 RNA extraction and real-time qPCR

486 Palatal tissue used for RNA isolation was dissected at desired stages and an RNeasy Plus Micro Kit 487 (Qiagen, 74034) was used to isolate the total RNA followed by cDNA synthesis using an iScript cDNA 488 synthesis kit (Bio-Rad, 1708891). Real-time qPCR quantification was done on a Bio-Rad CFX96 Real489 Time system using SsoFast EvaGreen Supermix (Bio-Rad, 1725201). Detailed information on primers is 490 listed in Supplementary File 3.

\section{ChIP-qPCR}


492 Palate tissue was dissected from control and $W n t 1^{C r e} ; K d m 6 b^{f l f l}$ mice at E13.5. Each replicate contained $493 \quad 60-80 \mathrm{mg}$ tissue combined from multiple animals. Samples were prepared following the manufacturer's 494 protocol (Chromatrap, 500191). Briefly, tissue was cut into small pieces and then fixed with $1 \%$ 495 formaldehyde at room temperature for 15 minutes, followed by incubating with $0.65 \mathrm{M}$ glycine solution. 496 Then the sample was washed twice with PBS, resuspended in Hypotonic Buffer and incubated at $4^{\circ} \mathrm{C}$ for 49710 minutes to obtain nuclei, which were then resuspended in Digestion Buffer. After chromatin was 498 sheared to 100-500 bp fragments using Shearing Cocktail, $10 \mu \mathrm{g}$ chromatin with H3K27me3 antibody 499 (CST 9733s, 1:50), DP1 antibody (Abcam ab124678, 1:10), KDM6B antibody (Abcepta AP1022b, 500 1:10), or Immunoglobulin $\mathrm{G}$ negative control $(2 \mu \mathrm{g})$ was added to Column Conditioning Buffer to make 501 up the final volume of $1000 \mu$ l. Immunoprecipitation (IP) slurry was mixed thoroughly and incubated on 502 an end-to-end rotor for 1 hour at $4{ }^{\circ} \mathrm{C}$. An equivalent amount of chromatin was set as an input. After 1 503 hour incubation, IP slurry was purified using Chromatrap® spin column at room temperature and 504 chromatin was eluted using ChIP-seq elution buffer. Chromatin sample and input were further incubated 505 at $65{ }^{\circ} \mathrm{C}$ overnight to reverse cross-linking. DNA was purified with Chromatrap® DNA purification 506 column after proteinase $\mathrm{K}$ treatment. ChIP eluates, negative control and input were assayed using real507 time qPCR. Primers were designed using the promoter region of Trp53. Detailed information is 508 available in Supplementary File 3.

\section{Western blot and Co-Immunoprecipitation}

510 For western blot, palate tissue was dissected from control and $W n t 1^{C r e} ; K d m 6 b^{f l f l}$ mice at E13.5. The 511 tissue sample was lysed using RIPA buffer (Cell Signaling, 9806) with protease inhibitor (Thermo 512 Fisher Scientific, A32929) for 20 minutes on ice followed by centrifugation at $4^{\circ} \mathrm{C}$ to remove tissue 513 debris. Protein extracts were then mixed with sample buffer (Bio-Rad, 1610747) and boiled at $98^{\circ} \mathrm{C}$ for 51410 minutes. Then denatured protein extract was separated in 4\%-15\% precast polyacrylamide gel (Bio- 
515 Rad, 456-1084) and then transferred to 0.45 $\mu \mathrm{m}$ PVDF membrane. Transferred membrane was incubated 516 with $5 \%$ milk for 1 hour at room temperature, and incubated with primary antibody at $4^{\circ} \mathrm{C}$ overnight. 517 After washing with TBST, membrane was incubated with secondary antibody for 2 hours at room 518 temperature and signals were detected using SuperSignal West Femto (Thermo Fisher Scientific, 34094) 519 and Azure 300 (Azure Biosystems).

520 For CoIP, palate tissue was dissected from control mice at E13.5 and 60-80 $\mathrm{mg}$ tissue was combined as 521 one sample for each replicate. After lysing using RIPA buffer, $60 \mu \mathrm{l}$ of the protein extract was mixed 522 with sample buffer and boiled at $98{ }^{\circ} \mathrm{C}$ to serve as input. The remaining protein extract was incubated 523 with primary antibody at $4{ }^{\circ} \mathrm{C}$ overnight. Protein $\mathrm{G}$ beads from GE Healthcare (GE Healthcare, 524 10280243) were used to purify the target protein and then the protein sample was analyzed using 525 western blot. Detailed information about primary and secondary antibodies is listed in Supplementary $526 \quad$ File 4.

\section{SiRNA and plasmid transfection}

528 Palatal tissue was dissected from control and $W n t 1^{C r e} ; K d m 6 b^{f l f l}$ mice at E13.5, then cut into small pieces 529 using a scalpel. This minced tissue was then cultured in DMEM medium (Gibco, 2192449) containing $53040 \%$ MSC FBS (Gibco, 2226685P) and 1\% Pen Strep (Gibco, 2145477) at $37^{\circ} \mathrm{C}$.

531 siRNA (Qiagen) and plasmid (OriGene) transfection was performed following the manufacturer's 532 protocol (Qiagen, 301704 and OriGene, TF81001). Briefly, siRNA was transfected into cells in 24-well 533 plates at $10 \mathrm{nM}$ for 3 days followed by qPCR and EdU proliferation assay. Plasmid was transfected into 534 cells in $24-w e l l$ plates using $1 \mu \mathrm{g} / \mu \mathrm{l}$ stock solution for 2 days followed by real-time qPCR. Primers 535 designed for qPCR are listed in Supplementary File 3. siRNA sequence and plasmid information are 536 listed in Supplementary File 5 and Supplementary File 6. 


\section{$537 \quad$ ATAC-seq analysis}

538 Palate tissue of E13.5 control mice was digested using TrypLE express enzyme (Thermo Fisher 539 Scientific, 12605010) and incubated at $37^{\circ} \mathrm{C}$ for 20 minutes with shaking at 600 rpm. Single-cell 540 suspension was prepared according to the 10X Genomics sample preparation protocol and processed to 541 generate ATAC-seq libraries according to a published protocol (Buenrostro et al. 2015). Sequencing was 542 performed using the NextSeq 500 platform (Illumina) and ATAC-seq reads were aligned to the UCSC 543 mm10 reference genome using BWA-MEN (Li 2013). Then ATAC-seq peaks were called by MACS2 544 and annotated. Known transcription factor biding motifs were analyzed by HOMER (Zhang et al. 2008; 545 Heinz et al. 2010). Quality files for sequencing is listed in Supplementary File 7.

\section{Cell differentiation assay}

547 Palatal tissue was dissected from control and $W n t 1^{C r e} ; K d m 6 b^{f l f l}$ mice at E13.5 and cultured as previously 548 described. Then the differentiation assay was conducted according to the manufacturer's protocol 549 (Gibco, A1007201) (Chen et al. 2020). Briefly, mesenchymal cells were seeded into cell culture plates at 550 the desired concentration followed by incubation at $36^{\circ} \mathrm{C}$ in a humidified atmosphere of $5 \% \mathrm{CO}_{2}$ for the 551 required time (a minimum of 2 hours and up to 4 days). Then growth medium was replaced by complete 552 differentiation medium and cells were continuously incubated for 3 weeks under osteogenic conditions. 553 After specific periods of cultivation, cells were stained using 2\% Alizarin Red S solution (PH 4.2) 554 solution. Images were acquired using EPSON Scan and Keyence BZ-X710/810 microscopes. 555 Quantification of the Alizarin Red S staining was conducted according to the manufacturer's protocol 556 (ScienCell, 8678).

\section{$557 \quad$ Senescence $\beta$-Galactosidase staining}


558 Palatal tissue was dissected from control mice at E13.5, then cut into small pieces using a scalpel. This 559 minced tissue was then cultured in DMEM medium (Gibco, 2192449) containing 40\% MSC FBS 560 (Gibco, 2226685P) and 1\% Pen Strep (Gibco, 2145477) at $37^{\circ} \mathrm{C}$. A cell monolayer was stained using a 561 senescence $\beta$-Galactosidase staining kit (Cell Signaling, 9860) according to the manufacturer's protocol. 562 Images were acquired using a Keyence BZ-X710/810 microscope.

$563 \quad$ Nutlin-3 treatment

564 Nutlin-3 (Sigma, N6287) was dissolved in corn oil (Sigma, C8267) with 10\% DMSO (Sigma, D2650) 565 and given to pregnant mice on days $10.5,12.5$ and 14.5 of pregnancy at a dosage based on their weight $566(10 \mathrm{mg} / \mathrm{kg})(\mathrm{Li}$ et al. 2016). Then embryos were collected at E16.5 for analysis.

567 Statistics

568 Statistical analysis was completed using GraphPad Prism and significance was assessed by independent 569 two-tailed Student's t-test or ANOVA. The chosen level of significance for all statistical tests in this 570 study was $\mathrm{p}<0.05$. Data is presented as mean $\pm \mathrm{SEM} . \mathrm{N}=3$ samples were analyzed for each experimental 571 group unless otherwise stated.

\section{Acknowledgements}

573 We thank Bridget Samuels and Linda Hattemer for critical reading of the manuscript and also 574 acknowledge USC Libraries Bioinformatics Service for their assistance with data analysis. We thank the 575 USC Office of Research and the Norris Medical Library for the bioinformatics software and computing 576 resources. 
Figure 1. Loss of $K d m b b$ in $\mathrm{CNC}$-derived cells results in cleft palate

(A-B) Whole-mount oral view shows complete cleft palate phenotype in $W n t 1^{C r e} ; K d m 6 b^{f l f l}$ mice. Arrowhead in B indicates the cleft palate. Scale bar: $2 \mathrm{~mm}$. (C-D) CT imaging reveals that the palatine process of the maxilla and palatine bone are missing in $W n t 1^{C r e} ; K d m 6 b^{f l f l}$ mice. White arrowheads in $\mathrm{C}$ indicates palatine process of maxilla in control mice, and red arrows indicates palatine bone. White asterisk in D indicates missing palatine process of maxilla in $W n t 1^{C r e} ; K d m 6 b^{f l f l}$ mice and red asterisk in D indicates the missing palatine bone in $K d m 6 b$ mutant mice. Scale bars: $1 \mathrm{~mm}$. (E-F) Sagittal views of CT images demonstrate the locations of HE sections in G-R. Red lines indicate the locations of sections. Yellow arrow in E indicates palatal shelf and yellow asterisk in F indicates cleft. Scale bars: $1 \mathrm{~mm}$. (G-R) Histological analysis of control and $W n t 1^{C r e} ; K d m 6 b^{f l f l}$ mice. $\mathrm{H}, \mathrm{J}, \mathrm{L}, \mathrm{N}, \mathrm{P}$, and $\mathrm{R}$ are magnified images of boxes in $\mathrm{G}, \mathrm{I}, \mathrm{K}, \mathrm{M}, \mathrm{O}$, and Q, respectively. Asterisks in $\mathrm{M}, \mathrm{O}$, and $\mathrm{Q}$ indicate cleft in $K d m 6 b$ mutant mice. Scale bar: $200 \mu \mathrm{m}$. Mes: mesenchyme; PPM: palatine process of maxilla; PB: palatine bone.

Figure 2. Kdmbb is critical for proliferation and differentiation of CNC-derived palatal mesenchyme cells (A-B) Immunostaing of EdU at E13.5 after 2 hours of EdU labeling. Dotted lines indicate palatal shelf region. Dashed lines indicate the palatal region used for quantification in C. Scale bar: $50 \mu \mathrm{m}$. (C) Quantification of EdU+ cells represented in A and B. Asterisk indicates $\mathrm{P}<0.05$. (D-G) Co-localization of EdU and Ki67 at E13.5 after 48 hours of EdU labeling. Dotted lines indicate palatal shelf region. Dashed lines indicate the palatal region used for quantification in $\mathrm{H}$. F and $\mathrm{G}$ are magnified images of boxes in D and E. Arrows in $\mathrm{F}$ and $\mathrm{G}$ indicate representative cells that are only EdU+, while arrowheads indicate representative cells that are positive for both EdU and Ki67. Scale bar: $50 \mu \mathrm{m}$. (H) Quantification of EdU and Ki67 double-positive cells represented in $\mathrm{D}$ and E. Asterisk indicates $\mathrm{P}<0.05$. (I-L) Immunostaining of RUNX2 at indicated stages. Insets are higher magnification images of boxes in I-L. Asterisks in $\mathrm{J}$ and $\mathrm{L}$ indicate decreased RUNX2+ cells observed in $W n t 1^{C r e} ; K d m 6 b^{f l f l}$ mice. Scale bar: $50 \mu \mathrm{m}$. White dotted lines indicate the palatal region used for quantification in Q. (M-P) Immunostaining of SP7 at indicated stages. Insets are higher magnification images of boxes in O 
and P. Asterisk in P indicates decreased SP7+ cells observed in $W n t 1^{C r e} ; K d m 6 b^{f l f l}$ mice. Scale bar: $50 \mu \mathrm{m}$.

White dotted lines indicate the palatal region used for quantification in R. (Q-R) Quantification results for RUNX2+ and SP7+ cells represented in I-P. Asterisk indicates $\mathrm{P}<0.05$. (S-W) Osteogenenic differentiation assay using Alizarin red $\mathrm{S}$ staining. $\mathrm{W}$ is the quantification result of Alizarin red $\mathrm{S}$ staining represented in $\mathrm{S}$ and T. Scale bars: $2 \mathrm{~mm}$ in S and T; $200 \mu \mathrm{m}$ in U amd V. Asterisk indicates $\mathrm{P}<0.05$.

Figure 2-Source data 1 for $2 \mathrm{C}$

Figure 2-Source data 2 for $2 \mathrm{H}$

Figure 2-Source data 3 for $2 \mathrm{Q}$

Figure 2-Source data 4 for $2 \mathrm{R}$

Figure 2-source data 5 for $2 \mathrm{~W}$

\section{Figure 3. P53 signaling pathway is disturbed in $\mathrm{Wnt1}^{\mathrm{Cre}} ; \mathrm{Kdm} 6 b^{f l f l}$ mice}

(A) Bulk RNA-seq of palatal tissues collected at E12.5 represented in heatmap. Differentially expressed genes were selected using $\mathrm{P}<0.05$ and fold change $<-1.2$ or $>1.2$. (B) Top seven signaling pathways disturbed in $K d m 6 b$ mutant mice, identified by Ingenuity Pathway Analysis. Red box indicates the top upregulated pathway observed in $W n t 1^{C r e} ; K d m 6 b^{f l f l}$ sample. (C) Top ten signaling pathways identified by GO analysis using differentially expressed genes identified by bulk RNA-seq analysis. Red box indicates P53 signaling is one of the top 10 pathways. X-axis shows the percentage of genes hit against total number of pathways hit. (D-G) Expression of Trp53 at E13.5 using RNAscope in situ hybridization. Dotted lines in D and F indicate palatal shelf. $\mathrm{E}$ and $\mathrm{G}$ are magnified images of boxes in D and F. Asterisk in G indicates decreased expression of $\operatorname{Trp} 53$ observed in $W n t 1^{C r e} ; K d m 6 b^{f l f l}$ mice. Scale bar: $50 \mu \mathrm{m}$. (H) RT-qPCR quantification of Trp53 in palatal tissues collected at E13.5. Asterisk indicates $\mathrm{P}<0.05$. (I-L) Immunostaining of $\gamma \mathrm{H} 2 \mathrm{AX}$ at E13.5. Dotted lines in I and $\mathrm{K}$ indicate palatal shelf and dashed lines indicate quantification area. $\mathrm{J}$ and $\mathrm{L}$ are magnified images of boxes in I and $\mathrm{K}$, respectively. Arrowheads in $\mathrm{J}$ and $\mathrm{L}$ indicate representative $\gamma \mathrm{H} 2 \mathrm{AX}+$ cells. Scale bar: $50 \mu \mathrm{m}$. (M) Quantification of $\gamma \mathrm{H} 2 \mathrm{AX}+$ cells represented in I and K. Asterisk indicates $\mathrm{P}<0.05$. (N-Q) Co-localization of EdU and $\gamma \mathrm{H} 2 \mathrm{AX}$ at E13.5 after 2 hours of EdU labeling. Dotted lines in $\mathrm{N}$ and $\mathrm{P}$ indicate palatal shelf region, 
while dashed lines indicate the palatal region used for quantification in $\mathrm{R}$. $\mathrm{O}$ and $\mathrm{Q}$ are magnified images of boxes in $\mathrm{N}$ and $\mathrm{P}$, respectively. Red arrows in $\mathrm{O}$ and $\mathrm{Q}$ indicate representative EdU+ cells with less than 5 $\gamma \mathrm{H} 2 \mathrm{AX}$ foci, while white arrowheads indicate representative cells that are positive for EdU and with $>5 \gamma \mathrm{H} 2 \mathrm{AX}$ foci. Scale bar: $50 \mu \mathrm{m}$. (R) Quantification of EdU+ cells with $>5 \gamma \mathrm{H} 2 \mathrm{AX}$ foci represented in $\mathrm{N}$ and P. Asterisk indicates $\mathrm{P}<0.05$.

Figure 3-Source data 1 for $3 \mathrm{H}$

Figure 3-Source data 2 for $3 \mathrm{M}$

Figure 3-Source data 3 for 3R

Figure 4. Altered Trp53 expression is responsible for the developmental defects in $W_{n t 1}^{C r e} ; K_{d m 6 b^{f l f l}}$ mice $^{\text {ing }}$ (A-C) Cells collected from E13.5 palatal tissue are transfected with siRNA to knock down expression of Trp53. Cell proliferation is evaluated using EdU labeling 3 days after transfection. A and B show proliferation of cells assessed by EdU labeling. Difference in EdU+ cells between mock- and siRNA-transfected groups is quantified in C. Scale bar: $100 \mu \mathrm{m}$. Asterisk indicates $\mathrm{P}<0.05$. (D-F) Cells collected from E13.5 palatal tissue are transfected with siRNA to knock down expression of Trp53. DNA damage is evaluated using $\gamma \mathrm{H} 2 \mathrm{AX} 3$ days after transfection. D and E show $\gamma \mathrm{H} 2 \mathrm{AX}+$ cells. Difference in $\gamma \mathrm{H} 2 \mathrm{AX}+$ cells between mock- and siRNAtransfected groups is quantified in F. Scale bar: $100 \mu \mathrm{m}$. Asterisk indicates $\mathrm{P}<0.05$. (G-R) Histological analysis of control and $W n t 1^{C r e} ; K d m 6 b^{f l f l}$ mice treated with Nutlin-3. J, K, L, P, Q, and R are magnified images of boxes in G, H, I, M, N, and O, respectively. Scale bar: $200 \mu \mathrm{m}$. Mes: mesenchyme; PPM: palatine process of maxilla; PB: palatine bone.

Figure 4-Source data 1 for 4C

Figure 4-Source data 2 for 4F

Figure 5. Level of $\mathrm{H3K27} \mathrm{me} 3$ is antagonistically regulated by $K d m 6 b$ and $E z h 2$ during palatogenesis

(A-E) Contribution of $\mathrm{H} 3 \mathrm{~K} 27 \mathrm{me} 3$ in the palatal shelf is evaluated using immunostaining and western blot at E13.5. Dotted lines in A and C indicate palatal shelf region. B and D are magnified images of boxes in A and C. Asterisk in B indicates no accumulation of H3K27me3 observed in control mice. Arrowheads in D indicate 
accumulation of H3K27me3 observed in $W_{n t 1}{ }^{C r e} ; K d m 6 b^{f l f f l}$ mice. Scale bar: $50 \mu \mathrm{m}$. (F-J) Contribution of Ezhl in the palatal shelf is evaluated using RNAscope in situ hybridization and western blot at E13.5. Dotted lines in $\mathrm{F}$ and $\mathrm{H}$ indicate palatal shelf region. $\mathrm{G}$ and $\mathrm{I}$ are magnified images of boxes in $\mathrm{F}$ and $\mathrm{H}$. Arrowheads in $\mathrm{G}$ and $\mathrm{I}$ indicate representative Ezhl+ cells. Scale bar: $50 \mu \mathrm{m}$.(K-O) Contribution of EZH2 in the palatal shelf is evaluated using immunostaining and western blot at E13.5. Dotted lines in K and M indicate palatal shelf region. $\mathrm{L}$ and $\mathrm{N}$ are magnified images of boxes in $\mathrm{K}$ and $\mathrm{M}$. Arrowheads in $\mathrm{L}$ and $\mathrm{N}$ indicate representative EZH2+ cells. Scale bar: $50 \mu \mathrm{m}$. (P-V) Contribution of H3K27me3 in the palatal shelf of control mice, Kdm6b mutant mice and EZH2 haploinsufficient model is evaluated using immunostaining and western blot at E13.5. Dotted lines in $\mathrm{P}, \mathrm{R}$, and $\mathrm{T}$ indicate palatal shelf region. $\mathrm{Q}, \mathrm{S}$, and $\mathrm{U}$ are magnified images of boxes in $\mathrm{P}, \mathrm{R}$, and $\mathrm{T}$, respectively. Asterisks in $\mathrm{Q}$ and $\mathrm{U}$ indicate no accumulation of $\mathrm{H} 3 \mathrm{~K} 27 \mathrm{me} 3$ observed in control (Q) and $W n t 1^{\mathrm{Cre}} ; \mathrm{Kdm} 6 b^{f l f l t} ; E z h 2^{f l /+}$ mice (U). White arrowheads in S indicate accumulation of H3K27me3 observed in $W n t 1^{C r e} ; K d m 6 b^{f l f l}$ mice. Scale bar: $50 \mu \mathrm{m}$.

Figure 5-source data 1 for $5 \mathrm{E}$

Figure 5-source data 2 for $5 \mathrm{~J}$

Figure 5-source data 3 for 50

Figure 5-source data 4 for $5 \mathrm{~V}$

Figure 6. Haploinsufficiency of $E z h 2$ rescues cleft palate in $\mathrm{Wnt1}^{\mathrm{Cre}} ; \mathrm{Kdm}_{\mathrm{f}} \mathrm{b}^{\mathrm{fllf}} ; E z h 2^{f l /+}$ mice (A-C) CT images at PN0.5. White arrowheads in A and $\mathrm{C}$ indicate palatine process of maxilla observed in control and $W n t 1^{C r e} ; K d m 6 b^{f l / f l} ; E z h 2^{f l /+}$ rescue model. Red arrows in A and C indicate palatine bone observed in

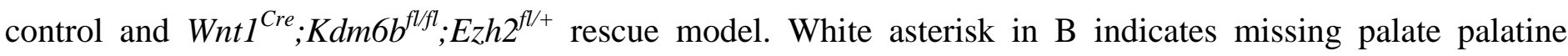
process of maxilla in $\mathrm{Wntl}^{\mathrm{Cre}} ; \mathrm{Kdm} 6 \mathrm{~b}^{\mathrm{flfl} \text { ll }}$ mice and red asterisk indicates missing palatine bone in $K d m 6 b$ mutant mice. Scale bar: $0.4 \mathrm{~mm}$. (D-F) Coronal views of CT images at PN0.5. Asterisk in E indicates cleft palate observed in $\mathrm{WntI}^{\mathrm{Cre}} ; \mathrm{Kdm} 6 b^{f l f l}$ mice. Scale bar: $0.3 \mathrm{~mm}$. (G-I) Whole-mount oral view at PN0.5. Arrowhead in $\mathrm{H}$ shows complete cleft palate observed in $\mathrm{Wntl}^{\mathrm{Cre}} ; \mathrm{Kdm}_{\mathrm{f}} \mathrm{b}^{\mathrm{flfl} l \mathrm{l}}$ mice. Dashed lines in G-I indicate location of sections in J-O. Scale bar: $2 \mathrm{~mm}$. (J-O) Histological analysis of samples at PN0.5. Asterisk in $\mathrm{K}$ and $\mathrm{N}$ indicates 
cleft palate in $\mathrm{Wntl}^{\mathrm{Cre}} ; \mathrm{Kdm} 6 b^{f l / f l}$ mice. M-O are magnified images of boxes in J-L, respectively. Dotted lines in M-O outline the bone structure. Scale bar: $200 \mu \mathrm{m}$. Mes: mesenchyme; PPM: palatine process of maxilla.

Figure 7. EdU+ and RUNX2+ cells are restored in $\mathrm{Wnt1}^{\mathrm{Cre}} ; \mathrm{Kdmbb}^{f l f l} ; \mathrm{Ezh}^{f l /+}$ mice.

(A-C) Immunostaining of EdU at E13.5 after 2 hours of EdU labeling. Dotted lines indicate palatal shelf region.

Dashed lines indicate the palatal region used for quantification in D. Scale bar: $50 \mu \mathrm{m}$. (D) Quantification of EdU+ cells represented in A-C. ANOVA is used for statistical analysis. Asterisk indicates P < 0.05 . N.S: not significant. (E-G) Immunostaining of RUNX2 at E13.5. Dotted lines indicate palatal shelf region. Dashed lines indicate the palatal region used for quantification in H. Scale bar: $50 \mu \mathrm{m}$. (H) Quantification of RUNX2+ cells represented in E-G. ANOVA is used for statistical analysis. Asterisk indicates $\mathrm{P}<0.05$. N.S: not significant.

Figure 7-source data 1 for 7D

Figure 7-source data 2 for $7 \mathrm{H}$

Figure 8. Kdm6b regulates expression of Trp53 through $\mathrm{H} 3 \mathrm{~K} 27 \mathrm{me} 3$ and interacts with transcription factor TFDP1 in activation of $\operatorname{Trp53}$

(A) ChIP-qPCR shows H3K27me3 deposition at the promoter region of $\operatorname{Trp} 53$ in palatal tissues of control, $K d m 6 b$ mutant, and Ezh2 haploinsufficient mice. ANOVA is used for statistical analysis. Asterisk indicates $\mathrm{P}<$ 0.05. N.S: not significant. (B-G) Expression of Trp53 in palatal region at E13.5 using RNAscope in situ hybridization. Dotted lines in B, C and D indicate palatal shelf. E, F, and G are magnified images of boxes in B, $\mathrm{C}$, and D, respectively. Asterisk in F indicates decreased expression of $\mathrm{Trp} 53$ observed in $\mathrm{Wntl}^{\mathrm{Cre}} ; \mathrm{Kdm} 6 \mathrm{~b}^{\mathrm{fl} f \mathrm{fl}}$ mice. Scale bar: $50 \mu \mathrm{m}$. (H) RT-qPCR analysis of Trp53 expression in the palatal region of control, $K d m 6 b$ mutant and Ezh2 haploinsufficient mice. ANOVA is used for statistical analysis. Asterisk indicates $\mathrm{P}<0.05$. . N.S: not significant. (I) ChIP-qPCR shows KDM6B deposition at the promoter region of Trp53 in the palatal tissue of control mice. Asterisk indicates $\mathrm{P}<0.05$. (J-K) RT-qPCR analysis of Trp53 expression in palatal mesenchymal cells transfected with $K d m 6 b$ - or $K d m 6 a$-overexpressing plasmids. Asterisk indicates $\mathrm{P}<0.05$. N.S: not significant. (L) ATAC-seq analysis indicates that promoter region of Trp53 is accessible for transcription factor TFDP1. (M) ChIP-qPCR using palatal tissue shows that binding of TFDP1 to the promoter 
of Trp53 decreases in the $K d m 6 b$ mutant mice. Asterisk indicates $\mathrm{P}<0.05$. N.S: not significant. (N-O) Colocalization of TFDP1, Kdm6b and Trp53 at E13.5 using immunostaining and RNAscope in situ hybridization. Dotted lines in $\mathrm{N}$ indicate palatal shelf. $\mathrm{O}$ is a magnified image of the box in $\mathrm{N}$. Arrowheads in $\mathrm{O}$ indicate representative cells that are positive for TFDP1, Kdm6b and Trp53. Scale bar: $50 \mu \mathrm{m}$ in $\mathrm{N}$ and $5 \mu \mathrm{m}$ in $\mathrm{O}$. (P) RT-qPCR quantification shows the expression of Tfdpl in samples collected at E13.5. N.S: not significant. (Q) RT-qPCR analysis of Trp53 expression in palatal mesenchymal cells after Tfdpl siRNA transfection. Asterisk indicates $\mathrm{P}<0.05$. (R-S) RT-qPCR analysis of Trp53 expression in palatal mesenchymal cells transfected with Tfdp1 overexpressing plasmid. Asterisk in $\mathrm{R}$ indicates $\mathrm{P}<0.05$. N.S: not significant. (T) Co-IP experiment using protein extract from palatal tissues indicates that KDM6B and TFDP1 are present in the same complex. Anti-KDM6B antibody was used for immunoprecipitation. IgG served as negative control. IP: immunoprecipitation. IB: immunoblotting.

Figure 8 -source data 1 for $8 \mathrm{~A}$

Figure 8-source data 2 for $8 \mathrm{H}$

Figure 8-source data 3 for $8 \mathrm{I}$

Figure 8-source data 4 for $8 \mathrm{~J}$

Figure 8-source data 5 for $8 \mathrm{~K}$

Figure 8 -source data 6 for $8 \mathrm{M}$

Figure 8-source data 7 for $8 \mathrm{P}$

Figure 8 -source data 8 for $8 Q$

Figure 8-source data 9 for $8 \mathrm{R}$

Figure 8-source data 10 for $8 \mathrm{~S}$

Figure 8-source data 11 for $8 \mathrm{~T}$

Figure 9. Summary schematic drawing

Figure 1-figure supplement 1. Expression of KDM6 family 
(A-L) Expression of KDM6 family genes in the palatal region at E13.5 using RNAscope in situ hybridization. D, E, F, J, K, and L are magnified images of boxes in A, B, C, G, H, and I respectively. Dotted lines in A, B, C, G, $\mathrm{H}$, and I indicate region of palatal shelf. Dotted lines in D, E, F, J, K, and L indicate epithelium. Schematic drawing at bottom of the figure indicates the location of the presented section. Scale bar: $50 \mu \mathrm{m}$. PS: palatal shelf; Mes: mesenchyme; Epi: epithelium. (M-N) Protein quantification of KDM6A and KDM6B in control and $K d m 6 b$ mutant palatal region at E13.5 using western blot. (O-P) Expression of $K d m 6 b$ in the first pharyngeal arch at E9.5 assessed using RNAscope in situ hybridization. Arrows in $\mathrm{P}$ indicate expression of $K d m 6 b$ at epithelium. PA1: first pharyngeal arch. Scale bar: $50 \mu \mathrm{m}$.

Figure 1-figure supplement 1-source data 1 for $1 \mathrm{M}$

Figure 1-figure supplement 1 -source data 2 for $1 \mathrm{~N}$

\section{Figure 1-figure supplement 2. Loss of $K d m 6 b$ in epithelium and CNC-derived cells}

(A-C and E-G) CT images and histological analysis of $K r t 14^{C r e} ; K d m 6 b^{f l f l}$ mice at PN0.5. Scale bars in A and E: $0.4 \mathrm{~mm}$; Scale bars in B and F: $0.6 \mathrm{~mm}$; Scale bars in C and G: $100 \mu \mathrm{m}$. (D and H) Expression of $K d m 6 b$ assessed using RNAscope in situ hybridization at E13.5. Kdm6b is efficiently knocked out from epithelium in $K r t 14^{C r e} ; K d m 6 b^{f l f l}$ mice. Dotted lines in D and H indicate epithelium. Scale bar: $100 \mu \mathrm{m}$. Epi: epithelium; DE: dental epithelium. (I-N) No obvious phenotype was observed in skull bones or mandible in $W n t 1^{C r e} ; K d m 6 b^{f l f l}$ mice at PN0.5. Yellow triangles in $\mathrm{J}$ and $\mathrm{M}$ indicate location of palatine process of maxilla and red triangle indicates location of palatine bone. Arrowhead in $\mathrm{N}$ indicates flattened skull observed in $W n t 1^{\mathrm{Cre}} ; \mathrm{Kdm}_{\mathrm{f}} 6 b^{f l f l}$ mice. Scale bar in I and L: $0.6 \mathrm{~mm}$; Scale bar in J and M: $1 \mathrm{~mm}$.

\section{Figure 1-figure supplement 3. Loss of $K d m b b$ in $\mathrm{CNC}$-derived cells results in soft palate muscle defects}

(A-P) Histological analysis of soft palate muscles at PN0.5. Boxes in A, B, C, D, I, J, K, and L are shown magnified in E, F, G, H, M, N, O, and P, respectively. Dotted lines outline each muscle. Asterisks in I, J, K, and L indicate cleft palate observed in $W n t 1^{C r e} ; K d m 6 b^{f l f l}$ mice. PP: pterygoid plate; PLG: palatoglossus; TVP: tensor veli palatini; LVP: levator veli palatini; PLP: palatopharyngeus. Scale bar: $100 \mu \mathrm{m}$. Asterisks in I-L indicate cleft in $W n t 1^{C r e} ; K d m 6 b^{f l f l}$ mice. (Q-X) Immunostaining of MHC at PN0.5. Dotted lines outline each 
muscle. PLG: palatoglossus; TVP: tensor veli palatini; LVP: levator veli palatini; PLP: palatopharyngeus. Scale bar: $50 \mu \mathrm{m}$.

\section{Figure 2-figure supplement $1 . K d m b b$ is not required for CNCCs to populate pharyngeal arches but is} critical for survival of palatal mesenchymal cells

(A-B) Whole-mount images of tdTomato reporter mice at E10.5. Arrowheads indicate CNCCs that have successfully migrated to the pharyngeal arch at E10.5. No differences were observed between control and $W n t 1^{C r e} ; K d m 6 b^{f l f l}$ mutant mice. Insets show immunostaining of tdTomato at E10.5. Dotted lines in the insets indicate first pharyngeal arch. PA1: first pharyngeal arch. Scale bars: $1 \mathrm{~mm}$. (C-D) Histological analysis of samples at E14.5. Asterisk in D indicates cleft palate observed in $\mathrm{Wnt}^{\mathrm{Cre}} ; \mathrm{Kdm} 6 b^{f l / f l}$ mice. PS: palatal shelf. Scale bar: $100 \mu \mathrm{m}$. (E-F) Senescence $\beta$-Galactosidase staining using cell culture from E13.5 palatal mesenchymal cells. Arrowheads in E and F indicate representative $\beta$-galactosidase+ cells. Scale bar: $100 \mu \mathrm{m}$. (G) Quantification of senescence-associated $\beta$-galactosidase activity represented in $\mathrm{E}$ and F. Asterisk indicates $\mathrm{P}$ $<0.05$. (H-K) Co-localization of EdU and Lamin B1 at E13.5 after 48 hours of EdU labeling. Dotted lines indicate palatal shelf region. Dashed lines indicate the palatal region used for quantification in L. J and $\mathrm{K}$ are magnified images of boxes in $\mathrm{H}$ and $\mathrm{I}$, respectively. Arrows in $\mathrm{J}$ indicate representative cells that are positive for both Lamin B1 and EdU, while arrowheads in K indicate representative cells that are EdU positive and Lamin B1 negative. Scale bar: $50 \mu \mathrm{m}$ in $\mathrm{H}$ and I, $25 \mu \mathrm{m}$ in J and K. (L) Quantification of cells that are EdU positive and Lamin B1 negative represented in $\mathrm{H}$ and I. Asterisk indicates $\mathrm{P}<0.05$.

Figure 2-figure supplement 1-source data 1 for $1 \mathrm{G}$

Figure 2-figure supplement 1-source data 1 for $1 \mathrm{~L}$

\section{Figure 4-figure supplement 1. Trp53 plays a critical role in regulating palatogenesis}

(A-C) RT-qPCR analysis of Trp53, Runx2 and $S p 7$ expression in cells isolated from palatal region of control mice 3 days after transfection with $\operatorname{Trp} 53$ siRNA. Asterisk indicates $\mathrm{P}<0.05$. (D-E) Histological analysis of samples treated with 10\% DMSO in corn oil at E10.5, E12.5 and E14.5. Asterisk in E indicates cleft palate 
776 observed in $W_{n t 1}{ }^{C r e} ; K d m 6 b^{f l f l}$ mouse. Scale bar: $200 \mu \mathrm{m}$. (F) P53 protein in the palatal region quantified using western blot. (G) Quantification of western blot represented in F. Asterisk indicates P $<0.05$. N.S: not significant.

Figure 4-figure supplement 1-source data 1 for $1 \mathrm{~A}$

Figure 4-figure supplement 1-source data 2 for 1B

Figure 4-figure supplement 1 -source data 3 for $1 \mathrm{C}$

Figure 4-figure supplement 1 -source data 4 for $1 \mathrm{~F}$

Figure 4-figure supplement 1-source data 5 for $1 \mathrm{G}$

Figure 8-figure supplement 1. KDM6B and transcription factors are involved in regulating Trp53

(A-B) RT-qPCR analysis of $K d m 6 a$ and $K d m 6 b$ expression in palatal mesenchymal cells isolated from Wnt $1 C r e ; K d m 6 b^{f l f l}$ mice after transfection with $K d m 6 a$ - or $K d m 6 b$ - overexpressing plasmids. Asterisks indicate $\mathrm{P}<0.05$. (C) ATAC-seq analysis suggests that the promoter of Trp53 is accessible to transcription factors E2F4 and E2F6. (D-E) Expression of Wrap53 in palatal region at E13.5 using RNAscope in situ hybridization. Dotted lines in D and E indicate palatal shelf. Scale bar: $50 \mu \mathrm{m}$. (F) Co-expression of $K d m 6 b$ and Tfdpl in the palate region at E13.5 using published scRNA-seq analysis (GEO: GSE155928). (G-H) Immunostaining of TFDP1 in the palatal region of control and $K d m 6 b$ mutant mice. Arrows indicate representative TFDP1+ cells. Scale bar: $50 \mu \mathrm{m}$. (I) RT-qPCR analysis of Tfdp1 expression in cells isolated from palatal region of control mice 3 days after transfection with Tfdp1 siRNA. Asterisk indicates P < 0.05. (J-K) RT-qPCR analysis of Tfdpl expression in palatal mesenchymal cells isolated from control and $K d m 6 b$ mutant mice after transfection with Tfdp1overexpressing plasmid. $\mathrm{J}$ represents the result using cells isolated from control mice and $\mathrm{K}$ represents the result using cells isolated from $\mathrm{WntI}^{\mathrm{Cre}} ; \mathrm{Kdm} 6 \mathrm{~b}^{\mathrm{flfl} l}$ mice. Asterisks indicate $\mathrm{P}<0.05$.

Figure 8-figure supplement 1-source data 1 for $1 \mathrm{~A}$

Figure 8-figure supplement 1-source data 2 for $1 \mathrm{~B}$

Figure 8-figure supplement 1-source data 3 for 1I

Figure 8-figure supplement 1-source data 4 for $1 \mathrm{~J}$ 
Figure 8-figure supplement 6 -source data 5 for $1 \mathrm{~K}$

Source Data Files

Figure 2-Source data 1 for $2 \mathrm{C}$

Figure 2-Source data 2 for $2 \mathrm{H}$

Figure 2-Source data 3 for $2 \mathrm{Q}$

Figure 2-Source data 4 for $2 \mathrm{R}$

Figure 2-source data 5 for $2 \mathrm{~W}$

Figure 3-Source data 1 for $3 \mathrm{H}$ 
827 Figure 3-Source data 2 for $3 \mathrm{M}$

828 Figure 3-Source data 3 for 3R

829 Figure 4-Source data 1 for $4 \mathrm{C}$

830 Figure 4-Source data 2 for 4F

831 Figure 5-source data 1 for 5E

832 Figure 5-source data 2 for $5 \mathrm{~J}$

833 Figure 5-source data 3 for $5 \mathrm{O}$

834 Figure 5-source data 4 for $5 \mathrm{~V}$

835 Figure 7-source data 1 for $7 \mathrm{D}$

836 Figure 7-source data 2 for $7 \mathrm{H}$

837 Figure 8-source data 1 for $8 \mathrm{~A}$

838 Figure 8 -source data 2 for $8 \mathrm{H}$

839 Figure 8-source data 3 for 8I

$840 \quad$ Figure 8 -source data 4 for $8 \mathrm{~J}$

841 Figure 8-source data 5 for $8 \mathrm{~K}$

842 Figure 8-source data 6 for $8 \mathrm{M}$

843 Figure 8-source data 7 for $8 \mathrm{P}$

844 Figure 8 -source data 8 for $8 \mathrm{Q}$

845 Figure 8-source data 9 for $8 \mathrm{R}$

846 Figure 8-source data 10 for $8 \mathrm{~S}$

847 Figure 8-source data 11 for $8 \mathrm{~T}$

848 Figure 1-figure supplement 1-source data 1 for $1 \mathrm{M}$

849 Figure 1-figure supplement 1-source data 2 for $1 \mathrm{~N}$

850 Figure 2-figure supplement 1-source data 1 for $1 \mathrm{G}$

851 Figure 2-figure supplement 1-source data 1 for $1 \mathrm{~L}$ 
852 Figure 4-figure supplement 1-source data 1 for $1 \mathrm{~A}$

853 Figure 4-figure supplement 1-source data 2 for 1B

854 Figure 4-figure supplement 1-source data 3 for 1C

855 Figure 4-figure supplement 1-source data 4 for $1 \mathrm{~F}$

856 Figure 4-figure supplement 1-source data 5 for $1 \mathrm{G}$

857

858

859

860

861

862

863

864

865

866

867

85

Figure 8-figure supplement 1 -source data 1 for $1 \mathrm{~A}$

Figure 8-figure supplement 1-source data 2 for 1B

Figure 8-figure supplement 1-source data 3 for 1I

Figure 8-figure supplement 1 -source data 4 for $1 \mathrm{~J}$

Figure 8-figure supplement 1-source data 5 for $1 \mathrm{~K}$ 


\section{References}

869

870

871

872

873

874

875

876

877

878

879

880

881

882

883

884

885

886

887

888

889

890

891

892

893

894

895

896

897

898

899

900

901

902

903

904

905

906

907

908

909

910

911

912

Arya AK, El-Fert A, Devling T, Eccles RM, Aslam MA, Rubbi CP, Vlatkovic N, Fenwick J, Lloyd BH, Sibson DR et al. 2010. Nutlin-3, the small-molecule inhibitor of MDM2, promotes senescence and radiosensitises laryngeal carcinoma cells harbouring wild-type p53. Br J Cancer 103: 186-195. https://doi.org/10.1038/sj.bjc.6605739

Bannister AJ, Kouzarides T. 2011. Regulation of chromatin by histone modifications. Cell Res 21: 381-395. https://doi.org/10.1038/cr.2011.22

Bernadotte A, Mikhelson VM, Spivak IM. 2016. Markers of cellular senescence. Telomere shortening as a marker of cellular senescence. Aging-Us 8: 3-11. https://doi.org/DOI 10.18632/aging.100871

Blagoev KB. 2009. Cell proliferation in the presence of telomerase. PLoS One 4: e4622. https://doi.org/10.1371/journal.pone.0004622

Bowen ME, Attardi LD. 2019. The role of p53 in developmental syndromes. J Mol Cell Biol 11: 200-211. https://doi.org/10.1093/jmcb/mjy087

Bowen ME, McClendon J, Long HK, Sorayya A, Van Nostrand JL, Wysocka J, Attardi LD. 2019. The Spatiotemporal Pattern and Intensity of p53 Activation Dictates Phenotypic Diversity in p53Driven Developmental Syndromes. Dev Cell 50: 212-228 e216. https://doi.org/10.1016/j.devcel.2019.05.015

Bruneau BG, Koseki H, Strome S, Torres-Padilla ME. 2019. Chromatin and epigenetics in development: a Special Issue. Development 146. https://doi.org/10.1242/dev.185025

Buenrostro JD, Wu B, Chang HY, Greenleaf WJ. 2015. ATAC-seq: A Method for Assaying Chromatin Accessibility Genome-Wide. Curr Protoc Mol Biol 109: $21 \quad 29 \quad 21-21 \quad 2929$. https://doi.org/10.1002/0471142727.mb2129s109

Bush JO, Jiang R. 2012. Palatogenesis: morphogenetic and molecular mechanisms of secondary palate development. Development 139: 231-243. https://doi.org/10.1242/dev.067082

Cardiff RD, Miller CH, Munn RJ. 2014. Manual hematoxylin and eosin staining of mouse tissue sections. Cold Spring Harb Protoc 2014: 655-658. https://doi.org/10.1101/pdb.prot073411

Chai Y, Maxson RE, Jr. 2006. Recent advances in craniofacial morphogenesis. Dev Dyn 235: 2353-2375. https://doi.org/10.1002/dvdy.20833

Chandler RL, Magnuson T. 2016. The SWI/SNF BAF-A complex is essential for neural crest development. Dev Biol 411: 15-24. https://doi.org/10.1016/i.ydbio.2016.01.015

Chandrasekharan D, Ramanathan A. 2014. Identification of a novel heterozygous truncation mutation in exon 1 of ARHGAP29 in an Indian subject with nonsyndromic cleft lip with cleft palate. Eur J Dent 8: 528-532. https://doi.org/10.4103/1305-7456.143637

Chen S, Jing JJ, Yuan Y, Feng JF, Han X, Wen Q, Ho TV, Lee C, Chai Y. 2020. Runx2+Niche Cells Maintain Incisor Mesenchymal Tissue Homeostasis through IGF Signaling. Cell Reports 32. https://doi.org/ARTN 108007

Cobourne MT, Xavier GM, Depew M, Hagan L, Sealby J, Webster Z, Sharpe PT. 2009. Sonic hedgehog signalling inhibits palatogenesis and arrests tooth development in a mouse model of the nevoid basal cell carcinoma syndrome. Dev Biol 331: 38-49. https://doi.org/10.1016/j.ydbio.2009.04.021

Cordero DR, Brugmann S, Chu Y, Bajpai R, Jame M, Helms JA. 2011. Cranial neural crest cells on the move: their roles in craniofacial development. Am J Med Genet A 155A: 270-279. https://doi.org/10.1002/ajmg.a.33702

den Broeder MJ, Ballangby J, Kamminga LM, Alestrom P, Legler J, Lindeman LC, Kamstra JH. 2020. Inhibition of methyltransferase activity of enhancer of zeste 2 leads to enhanced lipid 
accumulation and altered chromatin status in zebrafish. Epigenetics Chromatin 13: 5. https://doi.org/10.1186/s13072-020-0329-y

Dimitrova E, Turberfield AH, Klose RJ. 2015. Histone demethylases in chromatin biology and beyond. EMBO Rep 16: 1620-1639. https://doi.org/10.15252/embr.201541113

Dixon MJ, Marazita ML, Beaty TH, Murray JC. 2011. Cleft lip and palate: understanding genetic and environmental influences. Nat Rev Genet 12: 167-178. https://doi.org/10.1038/nrg2933

Flavahan WA, Gaskell E, Bernstein BE. 2017. Epigenetic plasticity and the hallmarks of cancer. Science 357. https://doi.org/10.1126/science.aal2380

Gokbuget D, Blelloch R. 2019. Epigenetic control of transcriptional regulation in pluripotency and early differentiation. Development 146. https://doi.org/10.1242/dev.164772

Grosshans BL, Grotsch H, Mukhopadhyay D, Fernandez IM, Pfannstiel J, Idrissi FZ, Lechner J, Riezman H, Geli MI. 2006. TEDS site phosphorylation of the yeast myosins I is required for ligand-induced but not for constitutive endocytosis of the G protein-coupled receptor Ste2p. Journal of Biological Chemistry 281: 11104-11114. https://doi.org/10.1074/jbc.M508933200

Gurrion C, Uriostegui M, Zurita M. 2017. Heterochromatin Reduction Correlates with the Increase of the KDM4B and KDM6A Demethylases and the Expression of Pericentromeric DNA during the Acquisition of a Transformed Phenotype. J Cancer 8: 2866-2875. https://doi.org/10.7150/ica.19477

Han X, Feng J, Guo T, Loh YE, Yuan Y, Ho TV, Cho CK, Li J, Jing J, Janeckova E et al. 2021. Runx2-Twist1 interaction coordinates cranial neural crest guidance of soft palate myogenesis. Elife 10. https://doi.org/10.7554/eLife.62387

Hanna CW, Demond H, Kelsey G. 2018. Epigenetic regulation in development: is the mouse a good model for the human? Hum Reprod Update 24: 556-576. https://doi.org/10.1093/humupd/dmy021

He F, Chen Y. 2012. Wnt signaling in lip and palate development. Front Oral Biol 16: 81-90. https://doi.org/10.1159/000337619

Heinz S, Benner C, Spann N, Bertolino E, Lin YC, Laslo P, Cheng JX, Murre C, Singh H, Glass CK. 2010. Simple combinations of lineage-determining transcription factors prime cis-regulatory elements required for macrophage and B cell identities. Mol Cell 38: 576-589. https://doi.org/10.1016/j.molcel.2010.05.004

Henckel A, Toth S, Arnaud P. 2007. Early mouse embryo development: could epigenetics influence cell fate determination? Bioessays 29: 520-524. https://doi.org/10.1002/bies.20591

Hobbs CA, Chowdhury S, Cleves MA, Erickson S, MacLeod SL, Shaw GM, Shete S, Witte JS, Tycko B. 2014. Genetic epidemiology and nonsyndromic structural birth defects: from candidate genes to epigenetics. JAMA Pediatr 168: 371-377. https://doi.org/10.1001/jamapediatrics.2013.4858

Hu N, Strobl-Mazzulla P, Sauka-Spengler T, Bronner ME. 2012. DNA methyltransferase3A as a molecular switch mediating the neural tube-to-neural crest fate transition. Genes Dev 26: 2380-2385. https://doi.org/10.1101/gad.198747.112

Hu N, Strobl-Mazzulla PH, Bronner ME. 2014. Epigenetic regulation in neural crest development. Dev Biol 396: 159-168. https://doi.org/10.1016/j.ydbio.2014.09.034

Jambhekar A, Dhall A, Shi Y. 2019. Roles and regulation of histone methylation in animal development. Nat Rev Mol Cell Biol 20: 625-641. https://doi.org/10.1038/s41580-019-0151-1

Jiang W, Wang J, Zhang Y. 2013. Histone H3K27me3 demethylases KDM6A and KDM6B modulate definitive endoderm differentiation from human ESCs by regulating WNT signaling pathway. Cell Res 23: 122-130. https://doi.org/10.1038/cr.2012.119

Jones NC, Lynn ML, Gaudenz K, Sakai D, Aoto K, Rey JP, Glynn EF, Ellington L, Du C, Dixon J et al. 2008. Prevention of the neurocristopathy Treacher Collins syndrome through inhibition of p53 function. Nature Medicine 14: 125-133. https://doi.org/10.1038/nm1725 
Kang S, Chovatiya G, Tumbar T. 2019. Epigenetic control in skin development, homeostasis and injury repair. Exp Dermatol 28: 453-463. https://doi.org/10.1111/exd.13872

Kim H, Kim D, Choi SA, Kim CR, Oh SK, Pyo KE, Kim J, Lee SH, Yoon JB, Zhang Y et al. 2018. KDM3A histone demethylase functions as an essential factor for activation of JAK2-STAT3 signaling pathway. Proc Natl Acad Sci U S A 115: 11766-11771. https://doi.org/10.1073/pnas.1805662115

Kim KC, Friso S, Choi SW. 2009. DNA methylation, an epigenetic mechanism connecting folate to healthy embryonic development and aging. J Nutr Biochem 20: 917-926. https://doi.org/10.1016/i.jnutbio.2009.06.008

Kim WT, Kim H, Katanaev VL, Joon Lee S, Ishitani T, Cha B, Han JK, Jho EH. 2012. Dual functions of DP1 promote biphasic Wnt-on and Wnt-off states during anteroposterior neural patterning. EMBO J 31: 3384-3397. https://doi.org/10.1038/emboj.2012.181

Klemm SL, Shipony Z, Greenleaf WJ. 2019. Chromatin accessibility and the regulatory epigenome. Nat Rev Genet 20: 207-220. https://doi.org/10.1038/s41576-018-0089-8

Kohn MJ, Bronson RT, Harlow E, Dyson NJ, Yamasaki L. 2003. Dp1 is required for extra-embryonic development. Development 130: 1295-1305. https://doi.org/10.1242/dev.00355

Lee YH, Saint-Jeannet JP. 2011. Sox9 function in craniofacial development and disease. Genesis 49: 200208. https://doi.org/10.1002/dvg.20717

Leoyklang P, Suphapeetiporn K, Siriwan P, Desudchit T, Chaowanapanja P, Gahl WA, Shotelersuk V. 2007. Heterozygous nonsense mutation SATB2 associated with cleft palate, osteoporosis, and cognitive defects. Hum Mutat 28: 732-738. https://doi.org/10.1002/humu.20515

Lessard JA, Crabtree GR. 2010. Chromatin regulatory mechanisms in pluripotency. Annu Rev Cell Dev Biol 26: 503-532. https://doi.org/10.1146/annurev-cellbio-051809-102012

Levi G, Mantero S, Barbieri O, Cantatore D, Paleari L, Beverdam A, Genova F, Robert B, Merlo GR. 2006. Msx1 and Dlx5 act independently in development of craniofacial skeleton, but converge on the regulation of Bmp signaling in palate formation. Mech Dev 123: 3-16. https://doi.org/10.1016/j.mod.2005.10.007

Li H. 2013. Aligning sequence reads, clone sequences and assembly contigs with BWA-MEM. arXiv:13033997v2 [q-bioGN].

Li Y, Stockton ME, Bhuiyan I, Eisinger BE, Gao Y, Miller JL, Bhattacharyya A, Zhao XY. 2016. MDM2 inhibition rescues neurogenic and cognitive deficits in a mouse model of fragile $X$ syndrome. $S c i$ Transl Med 8. https://doi.org/ARTN 336ra61

Lindgren AM, Hoyos T, Talkowski ME, Hanscom C, Blumenthal I, Chiang C, Ernst C, Pereira S, Ordulu Z, Clericuzio $C$ et al. 2013. Haploinsufficiency of KDM6A is associated with severe psychomotor retardation, global growth restriction, seizures and cleft palate. Hum Genet 132: 537-552. https://doi.org/10.1007/s00439-013-1263-x

Lu S, Yang Y, Du Y, Cao LL, Li M, Shen C, Hou T, Zhao Y, Wang H, Deng D et al. 2015. The transcription factor c-Fos coordinates with histone lysine-specific demethylase $2 \mathrm{~A}$ to activate the expression of cyclooxygenase-2. Oncotarget 6: 34704-34717. https://doi.org/10.18632/oncotarget.5474

Madisen L, Zwingman TA, Sunkin SM, Oh SW, Zariwala HA, Gu H, Ng LL, Palmiter RD, Hawrylycz MJ, Jones AR et al. 2010. A robust and high-throughput Cre reporting and characterization system for the whole mouse brain. Nat Neurosci 13: 133-140. https://doi.org/10.1038/nn.2467

Mahmoudi S, Henriksson S, Corcoran M, Mendez-Vidal C, Wiman KG, Farnebo M. 2009. Wrap53, a Natural p53 Antisense Transcript Required for p53 Induction upon DNA Damage. Molecular Cell 33: 462-471. https://doi.org/10.1016/i.molcel.2009.01.028

Manna S, Kim JK, Bauge C, Cam M, Zhao Y, Shetty J, Vacchio MS, Castro E, Tran B, Tessarollo L et al. 2015. Histone H3 Lysine 27 demethylases Jmjd3 and Utx are required for T-cell differentiation. Nat Commun 6: 8152. https://doi.org/10.1038/ncomms9152 
1008

1009

1010

1011

1012

1013

1014

1015

1016

1017

1018

1019

1020

1021

1022

1023

1024

1025

1026

1027

1028

1029

1030

1031

1032

1033

1034

1035

1036

1037

1038

1039

1040

1041

1042

1043

1044

1045

1046

1047

1048

1049

1050

1051

1052

1053

1054

Marino S, Vooijs M, van Der Gulden H, Jonkers J, Berns A. 2000. Induction of medulloblastomas in p53null mutant mice by somatic inactivation of $\mathrm{Rb}$ in the external granular layer cells of the cerebellum. Genes Dev 14: 994-1004.

Miermont A, Antolovic V, Lenn T, Nichols JME, Millward L, Chubb JR. 2019. The fate of cells undergoing spontaneous DNA damage during development. Development 146. https://doi.org/UNSP $\operatorname{dev} 174268$

Mijit M, Caracciolo V, Melillo A, Amicarelli F, Giordano A. 2020. Role of p53 in the Regulation of Cellular Senescence. Biomolecules 10. https://doi.org/10.3390/biom10030420

Molina-Serrano D, Kyriakou D, Kirmizis A. 2019. Histone Modifications as an Intersection Between Diet and Longevity. Front Genet 10: 192. https://doi.org/10.3389/fgene.2019.00192

Moller M, Schotanus K, Soyer JL, Haueisen J, Happ K, Stralucke M, Happel P, Smith KM, Connolly LR, Freitag $M$ et al. 2019. Destabilization of chromosome structure by histone H3 lysine 27 methylation. PLoS Genet 15: e1008093. https://doi.org/10.1371/journal.pgen.1008093

Nakamura Y, Yamamoto K, He XJ, Otsuki B, Kim Y, Murao H, Soeda T, Tsumaki N, Deng JM, Zhang ZP et al. 2011. Wwp2 is essential for palatogenesis mediated by the interaction between Sox 9 and mediator subunit 25. Nature Communications 2. https://doi.org/ARTN 251

Nelms BL, Labosky PA. 2010. in Transcriptional Control of Neural Crest Development, San Rafael (CA).

Noden DM. 1983. The role of the neural crest in patterning of avian cranial skeletal, connective, and muscle tissues. Dev Bio/ 96: 144-165. https://doi.org/10.1016/0012-1606(83)90318-4

-. 1991. Cell movements and control of patterned tissue assembly during craniofacial development. J Craniofac Genet Dev Biol 11: 192-213.

Parada C, Chai Y. 2012. Roles of BMP signaling pathway in lip and palate development. Front Oral Biol 16: 60-70. https://doi.org/10.1159/000337617

Pediconi N, Salerno D, Lupacchini L, Angrisani A, Peruzzi G, De Smaele E, Levrero M, Belloni L. 2019. EZH2, JMJD3, and UTX epigenetically regulate hepatic plasticity inducing retro-differentiation and proliferation of liver cells. Cell Death Dis 10: 518. https://doi.org/10.1038/s41419-019-1755$\underline{2}$

Reynolds K, Kumari P, Sepulveda Rincon L, Gu R, Ji Y, Kumar S, Zhou CJ. 2019. Wnt signaling in orofacial clefts: crosstalk, pathogenesis and models. Dis Model Mech 12. https://doi.org/10.1242/dmm.037051

Rigueur D, Lyons KM. 2014. Whole-mount skeletal staining. Methods Mol Biol 1130: 113-121. https://doi.org/10.1007/978-1-62703-989-5 9

Rinon A, Molchadsky A, Nathan E, Yovel G, Rotter V, Sarig R, Tzahor E. 2011. p53 coordinates cranial neural crest cell growth and epithelial-mesenchymal transition/delamination processes. Development 138: 1827-1838. https://doi.org/10.1242/dev.053645

Roessler E, Velez JI, Zhou N, Muenke M. 2012. Utilizing prospective sequence analysis of SHH, ZIC2, SIX3 and TGIF in holoprosencephaly probands to describe the parameters limiting the observed frequency of mutant gene $x$ gene interactions. Mol Genet Metab 105: 658-664. https://doi.org/10.1016/j.ymgme.2012.01.005

Ruijtenberg S, van den Heuvel S. 2016. Coordinating cell proliferation and differentiation: Antagonism between cell cycle regulators and cell type-specific gene expression. Cell Cycle 15: 196-212. https://doi.org/10.1080/15384101.2015.1120925

Satokata I, Maas R. 1994. Msx1 deficient mice exhibit cleft palate and abnormalities of craniofacial and tooth development. Nat Genet 6: 348-356. https://doi.org/10.1038/ng0494-348

Schwarz D, Varum S, Zemke M, Scholer A, Baggiolini A, Draganova K, Koseki H, Schubeler D, Sommer L. 2014. Ezh2 is required for neural crest-derived cartilage and bone formation. Development 141: 867-877. https://doi.org/10.1242/dev.094342 
1055

1056

1057

1058

1059

1060

1061

1062

1063

1064

1065

1066

1067

1068

1069

1070

1071

1072

1073

1074

1075

1076

1077

1078

1079

1080

1081

1082

1083

1084

1085

1086

1087

1088

1089

1090

1091

1092

1093

1094

1095

1096

1097

1098

1099

1100

Seelan RS, Mukhopadhyay P, Pisano MM, Greene RM. 2012. Developmental epigenetics of the murine secondary palate. ILAR J 53: 240-252. https://doi.org/10.1093/ilar.53.3-4.240

Sen R, Lencer E, Geiger EA, Jones KL, Shaikh TH, Artinger KB. 2020. The role of KMT2D and KDM6A in cardiac development: A cross-species analysis in humans, mice, and zebrafish. bioRxiv: 2020.2004.2003.024646. https://doi.org/10.1101/2020.04.03.024646

Shahbazi MN, Jedrusik A, Vuoristo S, Recher G, Hupalowska A, Bolton V, Fogarty NNM, Campbell A, Devito L, llic D et al. 2016. Self-organization of the human embryo in the absence of maternal tissues. Nat Cell Biol 18: 700-708. https://doi.org/10.1038/ncb3347

Shen X, Liu Y, Hsu YJ, Fujiwara Y, Kim J, Mao X, Yuan GC, Orkin SH. 2008. EZH1 mediates methylation on histone $\mathrm{H} 3$ lysine 27 and complements $\mathrm{EZH} 2$ in maintaining stem cell identity and executing pluripotency. Mol Cell 32: 491-502. https://doi.org/10.1016/j.molcel.2008.10.016

Shpargel KB, Starmer J, Wang C, Ge K, Magnuson T. 2017. UTX-guided neural crest function underlies craniofacial features of Kabuki syndrome. Proc Natl Acad Sci U S A 114: E9046-E9055. https://doi.org/10.1073/pnas.1705011114

Smith ZD, Meissner A. 2013. DNA methylation: roles in mammalian development. Nat Rev Genet 14: 204-220. https://doi.org/10.1038/nrg3354

Soares LM, He PC, Chun Y, Suh H, Kim T, Buratowski S. 2017. Determinants of Histone H3K4 Methylation Patterns. Mol Cell 68: 773-785 e776. https://doi.org/10.1016/i.molcel.2017.10.013

Soldatov R, Kaucka M, Kastriti ME, Petersen J, Chontorotzea T, Englmaier L, Akkuratova N, Yang YS, Haring $M$, Dyachuk V et al. 2019. Spatiotemporal structure of cell fate decisions in murine neural crest. Science 364: 971-+. https://doi.org/ARTN eaas9536

Sugii H, Grimaldi A, Li J, Parada C, Vu-Ho T, Feng J, Jing J, Yuan Y, Guo Y, Maeda H et al. 2017. The Dlx5FGF10 signaling cascade controls cranial neural crest and myoblast interaction during oropharyngeal patterning and development. Development 144: 4037-4045. https://doi.org/10.1242/dev.155176

Tateossian H, Morse S, Simon MM, Dean CH, Brown SD. 2015. Interactions between the otitis media gene, Fbxo11, and p53 in the mouse embryonic lung. Dis Model Mech 8: 1531-1542. https://doi.org/10.1242/dmm.022426

Trainor P, Krumlauf R. 2000. Plasticity in mouse neural crest cells reveals a new patterning role for cranial mesoderm. Nat Cell Biol 2: 96-102. https://doi.org/10.1038/35000051

Wiles ET, Selker EU. 2017. H3K27 methylation: a promiscuous repressive chromatin mark. Curr Opin Genet Dev 43: 31-37. https://doi.org/10.1016/i.gde.2016.11.001

Williams AB, Schumacher B. 2016. p53 in the DNA-Damage-Repair Process. Cold Spring Harb Perspect Med 6. https://doi.org/10.1101/cshperspect.a026070

Wilson S, Filipp FV. 2018. A network of epigenomic and transcriptional cooperation encompassing an epigenomic master regulator in cancer. NPJ Syst Biol Appl 4: 24. https://doi.org/10.1038/s41540-018-0061-4

Wysocka J, Swigut T, Xiao H, Milne TA, Kwon SY, Landry J, Kauer M, Tackett AJ, Chait BT, Badenhorst P et al. 2006. A PHD finger of NURF couples histone H3 lysine 4 trimethylation with chromatin remodelling. Nature 442: 86-90. https://doi.org/10.1038/nature04815

Xu J, Liu H, Lan Y, Aronow BJ, Kalinichenko VV, Jiang R. 2016. A Shh-Foxf-Fgf18-Shh Molecular Circuit $\begin{array}{lllll}\text { Regulating Palate Development. PLoS Genet 12: e1005769. } & \end{array}$ https://doi.org/10.1371/journal.pgen.1005769

Young JI, Slifer S, Hecht JT, Blanton SH. 2021. DNA Methylation Variation Is Identified in Monozygotic Twins Discordant for Non-syndromic Cleft Lip and Palate. Front Cell Dev Biol 9. https://doi.org/ARTN 656865 
1101 Yu L, Gu S, Alappat S, Song Y, Yan M, Zhang X, Zhang G, Jiang Y, Zhang Z, Zhang Y et al. 2005. Shox21102 deficient mice exhibit a rare type of incomplete clefting of the secondary palate. Development 1103 132: 4397-4406. https://doi.org/10.1242/dev.02013

1104 Zhang Y, Liu T, Meyer CA, Eeckhoute J, Johnson DS, Bernstein BE, Nusbaum C, Myers RM, Brown M, Li W 1105 et al. 2008. Model-based analysis of ChIP-Seq (MACS). Genome Biol 9: R137. 1106

1107 https://doi.org/10.1186/gb-2008-9-9-r137

Zhao H, Oka K, Bringas P, Kaartinen V, Chai Y. 2008. TGF-beta type I receptor Alk5 regulates tooth initiation and mandible patterning in a type II receptor-independent manner. Dev Biol 320: 1929. https://doi.org/10.1016/j.ydbio.2008.03.045

1111

Zoghbi HY, Beaudet AL. 2016. Epigenetics and Human Disease. Cold Spring Harb Perspect Biol 8: a019497. https://doi.org/10.1101/cshperspect.a019497 


\section{PN0.5}
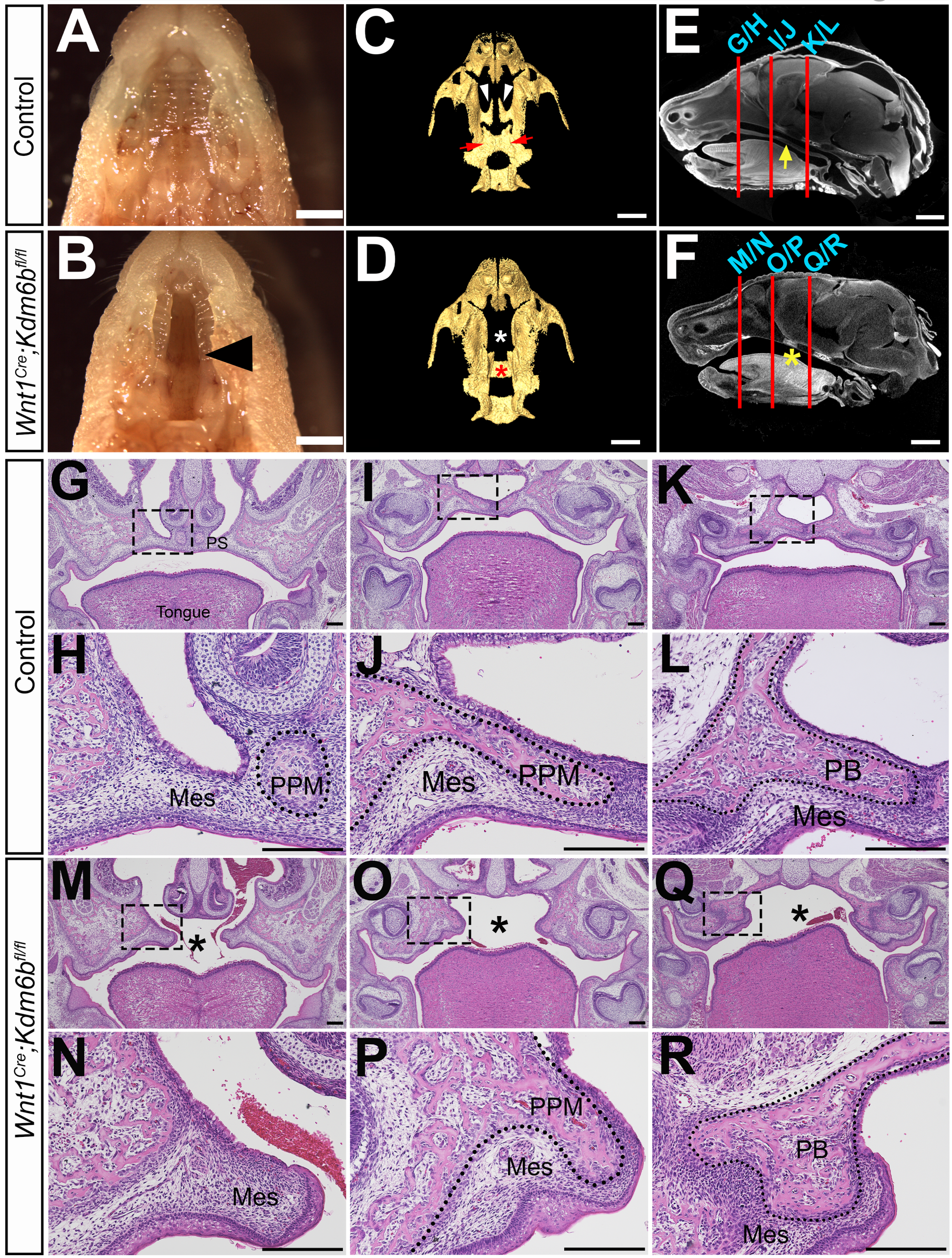

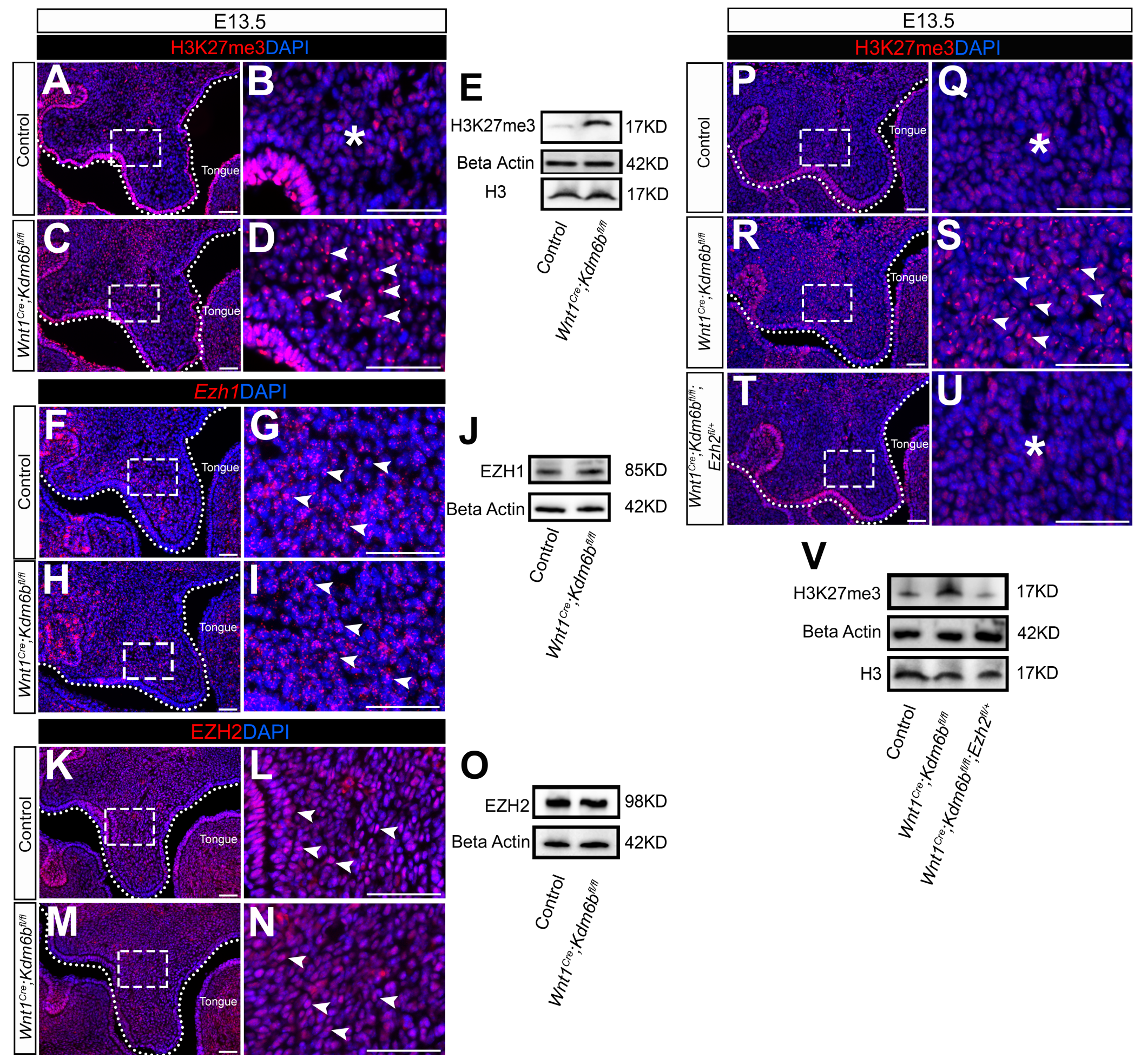


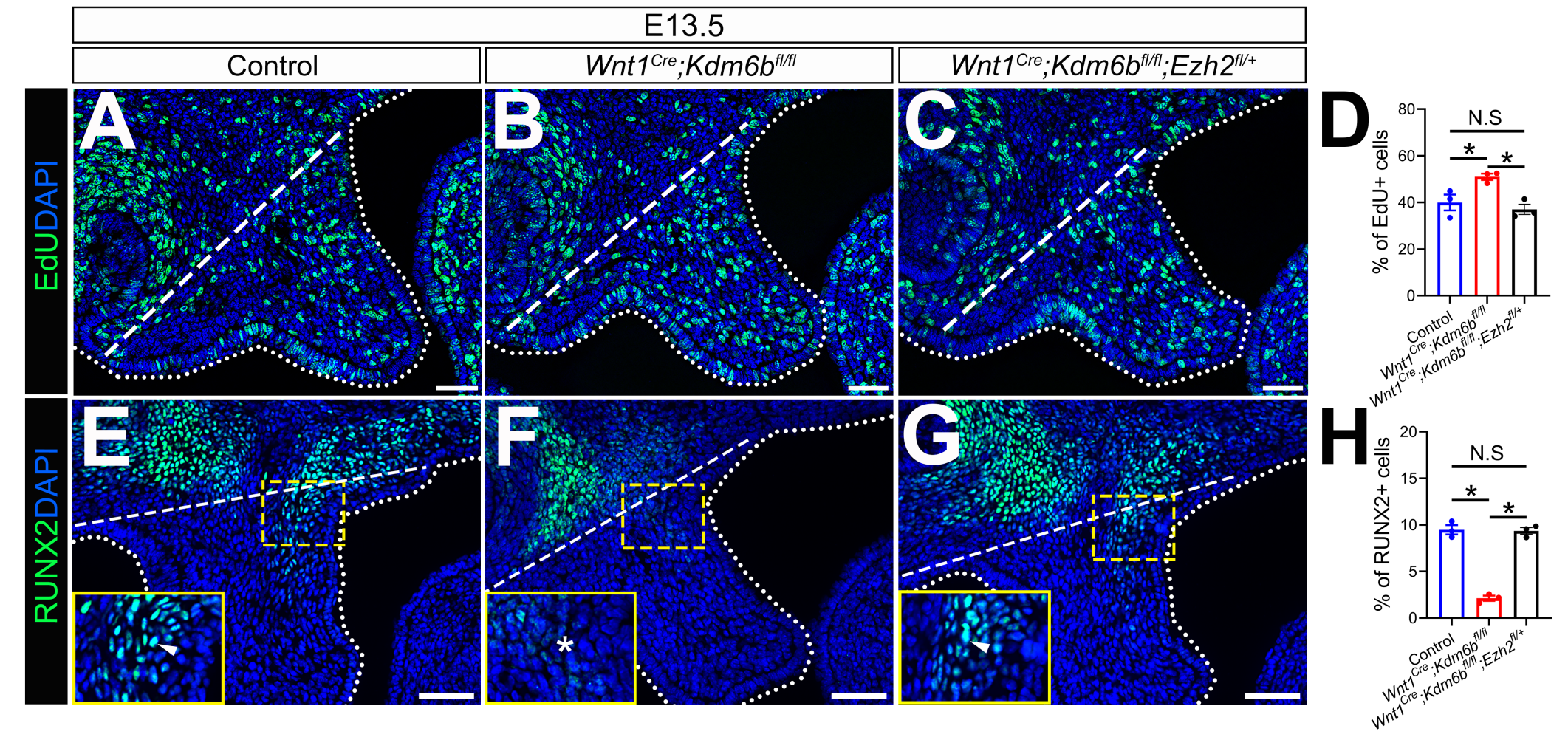




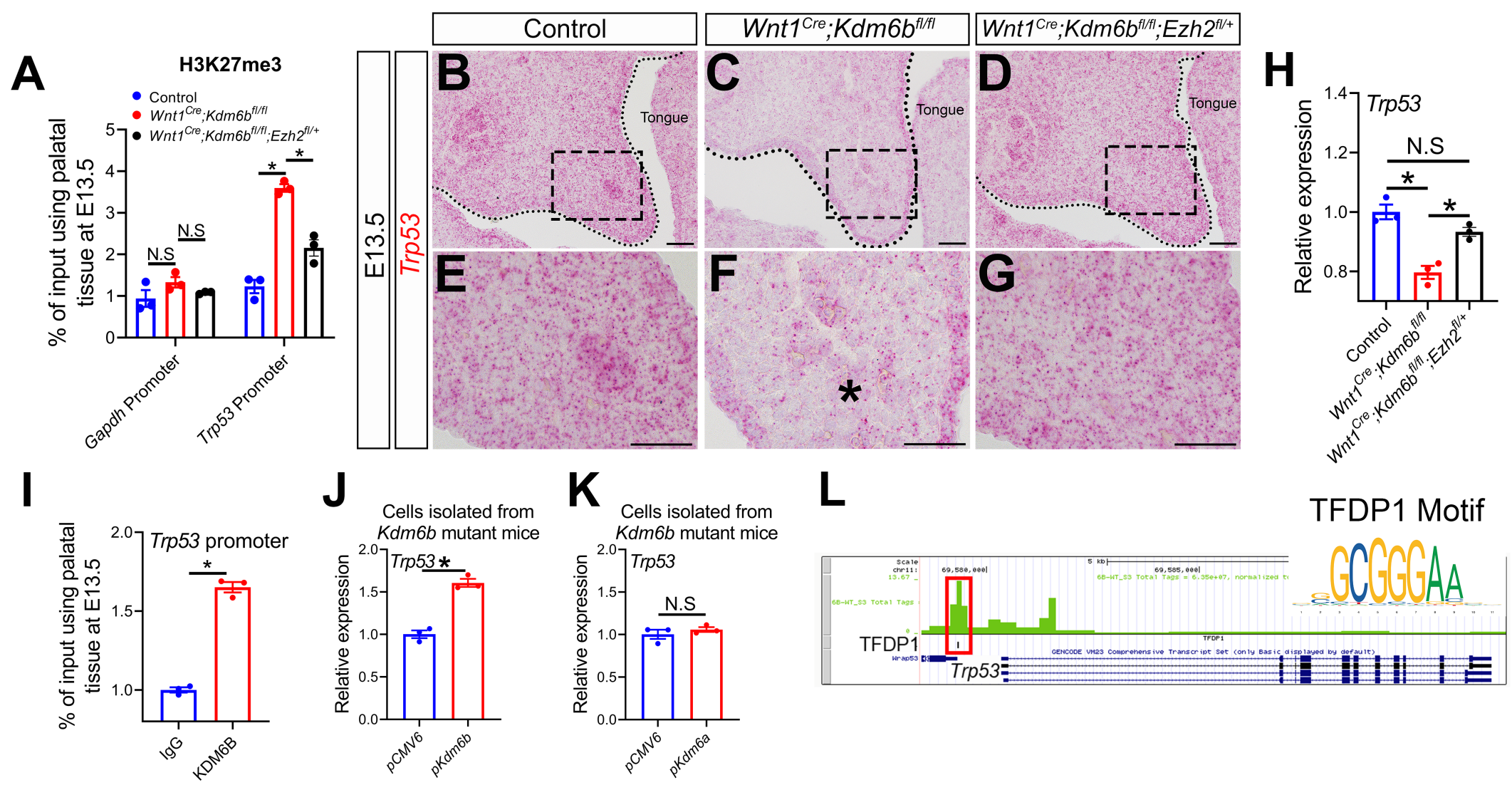

M
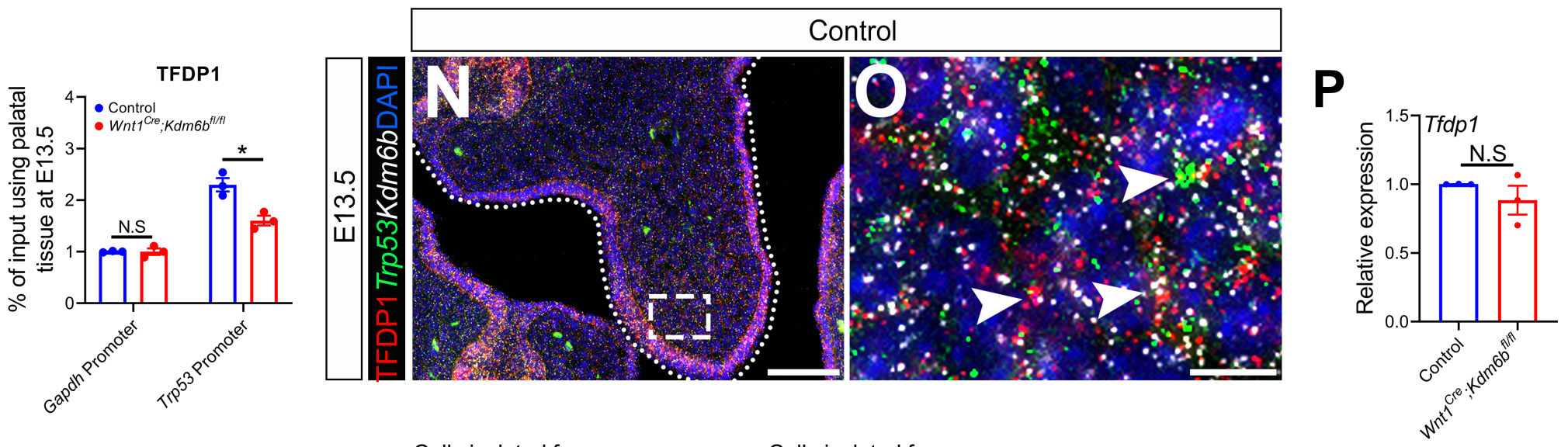

Q
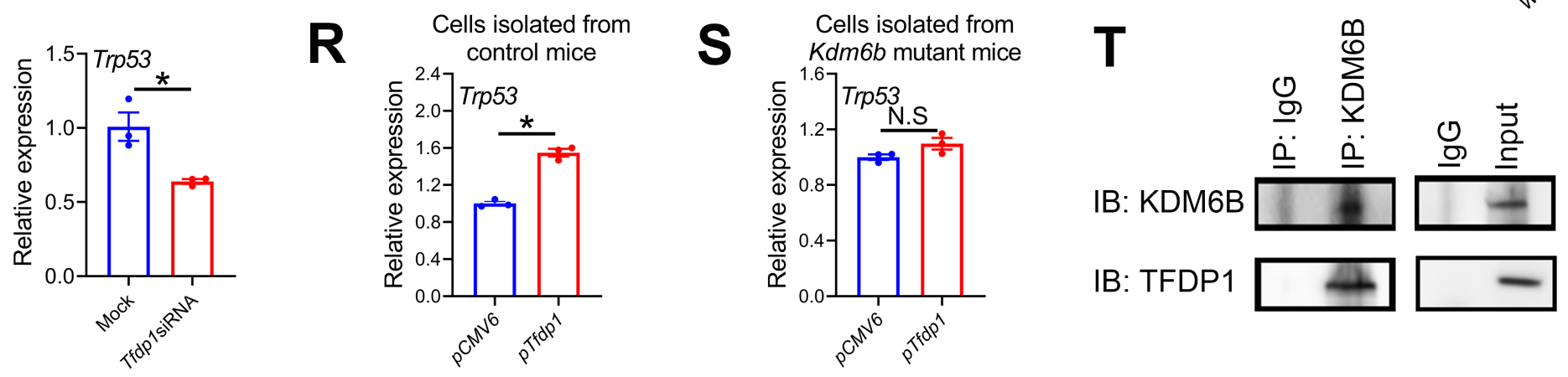

176KD $49 K D$ 


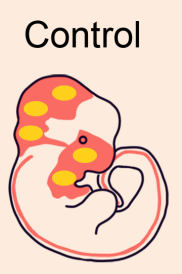

Transcription

Activation

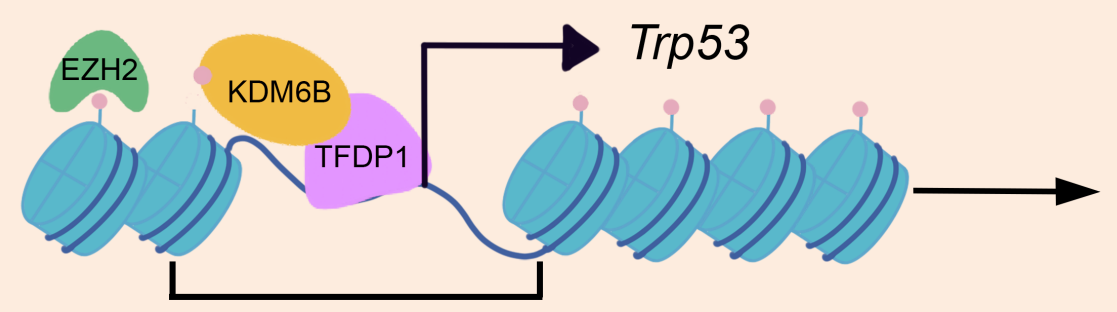
Normal craniofacial development

Trp53 Promoter

TFDP1

Wnt1 ${ }^{\text {Cre }} ; K d m 6 b^{f / f t}$

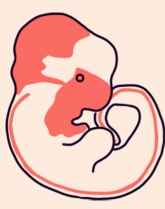

Transcription

Repression

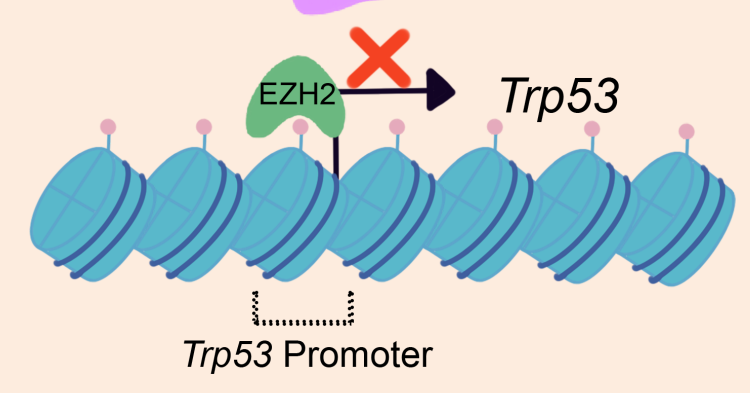

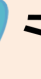

Differentiation defects

Hyperproliferation

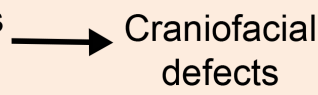

Trp53 Promoter

Increased cellular

senescence

Increased DNA

H3K27me3

TFDP1

EZH2 damage 